\title{
Úloha chyb, korektivní zpětné vazby a normy v cizojazyčné výuce $s$ důrazem na výuku angličtiny
}

\author{
Simona Kalová \\ Masarykova univerzita, Filozofická fakulta \\ Redakci zasláno 15. 7. 2016 / upravená verze obdržena 11. 2. 2018/ \\ k uveřejnění přijato 28. 2. 2018
}

\begin{abstract}
Abstrakt: Tato teoretická studie se zaměřuje na problematiku chyb a na úlohu, kterou hrají v cizojazyčné výuce, zejména ve výuce angličtiny. Jejím cílem je porovnat poznatky o chybách a korektivní zpětné vazbě z české i zahraniční odborné literatury a vyvodit z nich obecné principy, které by našly své uplatnění ve výuce. Podrobněji je pojednáno o otázkách jazykové normy, s důrazem na specifickou situaci normy v současném anglickém jazyce a její dopady na výuku angličtiny jako druhého a cizího jazyka. Tato problematika, v níž nepanuje v odborných kruzích shoda, představuje jedno z významných aktuálních témat ve výuce angličtiny, ale povědomí o ní v českém kontextu dosud není dostatečné. Po teoretickém vymezení klíčových pojmů chyba a norma v první kapitole následuje ve druhé kapitole přehled vývoje přístupu k chybám $\mathrm{v}$ diachronní perspektivě. Závěrečná část shrnuje poznatky nejnovějšího výzkumu o úloze chyb ve výuce angličtiny a naznačuje stěžejní principy př́stupu k chybám a poskytování zpětné vazby, které je ve výuce třeba respektovat tak, aby zpětná vazba byla pro učení přínosem, a ne překážkou. Důraz je potřeba klást zejména na volbu vhodných strategií poskytování korektivní zpětné vazby v závislosti na konkrétním kontextu výuky.
\end{abstract}

Klíčová slova: cizojazyčná výuka, výuka angličtiny, chyba, jazyková norma, korektivní zpětná vazba

V̌̌ivotě je třeba se mýlit. Mýlit se totiž znamená poznávat. Romain Rolland

Chybování je bezesporu nevyhnutelným průvodním znakem většiny lidských činností, při nichž dochází k osvojování nových dovedností. Chyby tedy neodmyslitelně patří ke vzdělávání a učitelé i žáci jsou s nimi denně konfrontováni. Ne vždy jsou však chyby chápány jako přirozená součást učení, často jsou odsuzovány, stigmatizovány a stávají se zdrojem napětí pro všechny aktéry výuky. Jinak tomu není ani v cizojazyčné výuce, na kterou se v tomto textu zaměříme. Prvním úskalím je vymezení tohoto poněkud neuchopitelného 
pojmu. Právě definice chyby bude předmětem úvodní kapitoly tohoto textu. Chybu vymezujeme zpravidla vůči obecně přijímanému kritériu správnosti, tedy normě. Ta má v cizojazyčné výuce svoji nezastupitelnou roli a její definice také není bez obtíží. Zvláště komplikovaná je situace s vymezením normy při výuce angličtiny, a to zejména v posledních desetiletích, kdy se postavení angličtiny mezi ostatními jazyky zásadním způsobem proměnilo a angličtina se stala jazykem mezinárodní komunikace, novodobou lingua franca. Vedle sebe tedy koexistuje tradiční norma rodilého mluvčího a nově vznikající norma, pro kterou se vžilo označení angličtina jako lingua franca - English as a lingua franca - ELF. ${ }^{1}$ Učitelé, žáci i tvůrci učebnic a výukových materiálů tedy stojí před nelehkým dilematem, kterou z těchto norem zvolit jako nejvhodnější pro výuku. Tato debata probíhá mezi odborníky i laiky již léta a nebyla doposud uspokojivě vyřešena. Volba vhodné normy pro výuku angličtiny tedy bezesporu patří k aktuálním tématům cizojazyčné výuky. Ve druhé kapitole je nastíněn vývoj př́istupu k chybám v cizojazyčné výuce v diachronní perspektivě. Různé metody a přístupy k výuce jazyků se od sebe značně lišily postojem $\mathrm{k}$ chybám, mimo jiné v závislosti na rozvoji lingvistiky, psychologie a pedagogiky. Mnohé poznatky z dnes již překonaných př́stupů však mají svůj význam pro současné, post-metodické období a jejich znalost tak může i současným učitelům napomoci při rozhodování o nejvhodnějším způsobu nakládání s chybami.

Třetí část tohoto textu se zaměřuje na konkrétní principy př́istupu k chybám, pohled na chyby $\mathrm{z}$ hlediska učitele a žáka a jejich přínos pro učení. Tyto poznatky jsou zakotveny v teoretickém systému osvojování druhého a cizího jazyka (second language acquisition - SLA). ${ }^{2}$ Podrobněji jsou zmíněny charakteristiky poskytování zpětné vazby, závěry vybraných empirických výzkumů a z nich pramenící poznatky a doporučení pro pedagogickou praxi.

\footnotetext{
V odborné literatuře posledních let se ustálilo používání termínu ELF, který nahradil starší termíny, např. English as an international language - EIL, global language (Crystal, 2003) nebo Global English (Jenkins, 2007, s. 3-4).

2 Teorie osvojování cizího jazyka bývá v zahraniční literatuře obvykle nazývána osvojování druhého jazyka (second language acquisition - SLA). Hovoříme-li však o procesech učení a osvojování v zemi, v níž se tímto cílovým - osvojovaným - jazykem nehovoří, je přesnější mluvit o osvojování cizího jazyka. Vzhledem k tomu, že zkratka SLA je vžitá v české i zahraniční literatuře, budeme ji i v této práci užívat pro označení osvojování druhého i cizího jazyka.
} 


\section{Teoretická východiska}

\subsection{Chyba}

Navzdory tomu, že chyba je neodmyslitelným průvodcem jakéhokoliv lidského snažení, úžeji učení, není snadné ji jednoznačně definovat (srov. Kulič, 1971, s. 91). Pokusme se tedy nyní tento pojem alespoň stručně vymezit.

Pedagogický slovník uvádí, že chyby jsou „výkony, které se odchylují od vzorového průběhu či zadaného cíle, nedostačují požadavkům, jsou nesprávné“ (Průcha, Walterová, \& Mareš, 2009, s. 98). Slavík nazývá chybou „nepřijatelný rozpor odhalený hodnoticím srovnáním jevu (,jak to aktuálně je') s jeho srovnávacím vzorem (,jak by to správně mělo být'), chyba je informací, která vyzývá ke změně daného stavu věcí - ke korekci, nápravě“ (1999, s. 71). Chyba v procesu učení tudíž přináší poznatky o výkonu žáka, o tom, zda bylo dosaženo výchovně-vzdělávacího cíle, stává se podstatnou součástí hodnocení.

Chybu lze tedy vnímat jako určitý signál, upozornění na odchylku, která však není nutně důkazem mylného řešení, ale může naopak znamenat inovativní postup, originalitu a kreativitu. Na tuto skutečnost upozorňuje již Kulič (1971), který navrhuje, že je žádoucí a přínosné „chybných řešení nebo situací typu ,nevím využít k rozvíjení myšlení a k osvojování metod řešení problémů“ (s. 90) a vnímá chybu jako inspiraci k novému pohledu na zkoumanou situaci a z toho pramenící možnost přijít s novým, neotřelým řešením.

Navzdory skutečnosti, že zájem o možnosti využití chyby ve výuce u odborné veřejnosti přetrvává, a to jak v publikacích (srov. např. Hrdlička, 2012; Ondráková, 2014; Slavík, 1994, 1999), tak na konferencích zaměřených na tuto problematiku (Švrčinová, 2014), a je potvrzen i empirickým výzkumem (Šed'ová \& Švaříček, 2010, 2012), každodenní situace v české škole tomu často neodpovídá. „Náš český a slovenský učitelský přístup k chybě je nasycen předsudky“, je proto nanejvýš žádoucí a aktuální „najít pádné argumenty proti těmto předsudkům a zejména pak hledat cesty, jak je možno daný stav změnit“ (Hejný, 2001, s. 72). Výsledky terénního výzkumu provedeného na druhém stupni ZŠ (Šed'ová \& Švaříček, 2010) naznačují, že cílená práce $\mathrm{s}$ chybou a korektivní zpětnou vazbou není, i přes své nesporné klady, doposud v české škole dostatečně využívána.

Z výše zmíněného vyplývá, že chyba je stále často vymezována jako jev spíše nežádoucí, nesprávný, nepřijatelný, svědčící o nedostatečnosti hodnoceného 
výkonu. Opomíjena je přirozenost a nevyhnutelnost chyb a jejich přínos pro učení. Přestože negativní přístup k roli chyby je typický pro starší a dnes již do značné míry překonané teorie učení, jak o nich bude pojednáno dále v tomto textu, v pedagogické praxi se objevuje dosud. Zabývat se úlohou chyb a vhodnými způsoby, jak s nimi ve výuce nakládat, je tedy nanejvýš žádoucí. Chceme-li chybu využít jako př́ležitost k učení, je třeba ji vnímat ve dvou rovinách: nejprve jako signál jiného než očekávaného vývoje, přitahující pozornost, a ve druhé rovině pak vedle snahy o nápravu také jako možný podnět pro jiné, nové řešení.

\subsection{Norma}

Při vymezení chybného výkonu vyvstává potřeba definovat cílovou správnou podobu požadovaného výkonu, tedy normu, s níž daný výkon srovnáváme. Její stanovení a přesná charakteristika má klíčový význam pro učitele i žáka, nebot' jim napomáhá zjistit, do jaké míry se podařilo tomuto požadovanému výkonu přiblížit (srov. Mareš, 2013, s. 298). Objektivní a precizní stanovení normy je relativně snadné $\mathrm{v}$ oblasti exaktních věd, $\mathrm{v}$ nichž je očekávaný výkon zpravidla snadno měřitelný a numericky vyjádřitelný, zatímco v oblasti humanitních věd je hodnocení výkonu poměrně náročné, a ne vždy jednoznačné. Zajímavá je rovněž otázka, zda lze pracovat s chybným výkonem i v oblastech kreativních a výrazových, např́klad ve výtvarné, hudební či dramatické výchově (srov. Slavík, 1994, s. 119).

Za rozhodující ukazatel ve stanovení správné normy považuje Slavík kontext, v němž k chybě dochází. „Proměna kontextu se může stát rozhodující [...] chyba se ukáže jako vítaná cesta $\mathrm{k}$ dosud netušené formulaci cíle, [...] v nových souvislostech se správnost, tj. shoda se zastaralou normou, může projevit jako chyba." (srov. Slavík, 1994, s. 119-120). Shodně s Kuličem (1971, s. 90) pohlíží na chybný výsledek jako na př́nosnou informaci, v níž často i nesprávně zvolené, a tedy chybné prostředky, vedou ke správnému cíli. Pro ilustraci volí všeobecně známé příklady, v nichž zdánlivě chybný výkon vedl k překvapivě pozitivnímu výsledku, jako jsou Kolumbův objev Ameriky či Flemingovo objevení penicilinu. Touto perspektivou vnímaná aktuální situace a podmínky, za nichž k chybě dochází, vedou pak ke zjištění, že to, co se jevilo jako chybné, je v novém kontextu správné. Tento Slavíkův závěr, který aplikuje zejména na hodnocení výtvarných děl, nachází paralelu i v cizojazyčné výuce, nebot' jazyk jako živý organismus se rovněž vyvíjí, i na něj působí širší společensko-historický kontext a s tím dochází i k proměnlivosti při vytváření norem. 


\section{Pojetí jazykové normy v českém a slovenském kontextu}

$\mathrm{V}$ českém a slovenském kontextu vykazuje pojetí jazykové normy, kterou předjímá již pražská lingvistická škola a explicitně ji definuje v roce 1932 Havránek (Nebeská, 1999, s. 14), dvojí polohu - „normu chápanou obecně“ a „normu spisovného jazyka“ (Nebeská, 1999, s. 22). Toto dvojí pojetí však nebylo zpočátku výslovně vymezeno, patrně i proto, že ačkoliv jde o jeden ze základních termínů jazykovědy, je přesné vymezení normy problematické a bývá opakovaně kriticky přehodnocováno. „Ve vymezení jazykové normy je vždy určitá míra neostrosti, vágnosti; v pojmových soustavách zaujímá prostor kdesi mezi jazykem (langue), resp. jazykovým systémem a územ." (Homoláč \& Nebeská, 2000, s. 102). Při vytváření normy existuje tedy určitá rozporuplnost, „mezi normou a územ je stálé napětí (Nebeská, 1999, s. 35). To patrně pramení ze skutečnosti, že norma stojí mezi kodifikací, tedy uvědomělou snahou o kultivaci jazyka, který jako by byl „neustále tlačen k ukázněnosti“ (Quine, 2008, s. 129) na straně jedné, a územ na straně druhé. Právě úzus, tedy konkrétní užívání jazyka, a dále „změny v přirozeném prostředí a materiální kultuře" (ibid) působí na vývoj přípustných tvarů v jazyce. Explicitní rozdělení normy na polohu obecnou, stojící mezi jazykem jako systémem a používáním jazyka v řeči, územ, a na polohu specifickou, mezi územ a kodifikací, tedy jazykovou správností, umožňuje její přesnější vymezení (Nebeská, 1992, 1999). Norma je ve své specifické poloze závazná, společensky podmíněná a jednotná, přibližuje se normě spisovného jazyka, její dodržování je vyžadováno, současně však dynamicky reaguje na splnění potřeb účinné komunikace. Typickými rysy jazykové normy jsou inherentnost, tedy jakési ukotvení v jazyce jako systému, implicitnost, která se vztahuje k jazyku jako celku, a s tím související uvědomované a závazné konvence dodržované členy společenství, pravidelnost, bezpř́znakovost a závaznost, variantnost (Nebeská, 1999, s. 17-20; srov. také Kočiš, 1979; Kačala, 2009; Kumorová, 2015).

Přibližně od poloviny 20. století, s postupným odklonem od strukturalismu jako dominantního lingvistického směru, se zkoumání jazyka postupně více zaměřuje na jazyk jako prostředek komunikace, což se projevuje i v pojetí normy. Nově se objevuje hledisko normy stylové, která se, spíše než na jazykové prostředky jako takové, zaměřuje na jejich výběr v závislosti na pragmatických aspektech komunikace. Od 70. let 20. století se posiluje význam komunikační funkce jazyka, což se projevuje i ve vymezení funkčního a komunikačního aspektu normy, která je chápána jako variantní, jejíž závaznost 
je diferencovaná a v níž je „nejdůležitějším kritériem výběru jazykových prostředků [...] adekvátnost dané funkci“ (Homoláč \& Nebeská, 2000, s. 102). Lze tedy poněkud obecně říci, že „komunikační normy jsou [...] současně normami jazykovými a normami chování“ (Nebeská, 1999, s. 88-89) a dochází k posunu od dosavadního spíše kodifikovaného pojetí normy k normě chápané v širším slova smyslu jako konvenci (Homoláč \& Nebeská, 2000, s. 102).

V posledních letech se s rozvojem nové jazykovědné disciplíny, korpusové lingvistiky, objevují možnosti jak získat velké množství dat o jazykovém úzu, což přispívá k přesnému a objektivnímu popisu skutečně používaného jazyka (Cvrček \& Kováŕíková, 2011). To má svủj odraz i v novém vnímání pojmu norma u některých autorů. Objevují se tendence přehodnotit dosavadní, v českém kontextu doposud široce akceptovaný charakter institucionálně kodifikované podoby normy a teorie spisovnosti a jazykové kultury novým, poněkud kontroverzním př́stupem. Ten je založený na konceptu tzv. minimálních intervencí a, zjednodušeně řečeno, volá po omezení intervencí do jazyka ze strany lingvistů (Cvrček, 2008). Tento přístup však nachází prozatím odezvu spíše odmítavou (srov. napřr. Adam, 2008; Homoláč \& Mrázková, 2011) a nebudeme se jím na tomto místě blíže zabývat.

\section{Pojetí jazykové normy v mezinárodním kontextu}

Havránkův příspěvek na téma problematiky jazykové normy, přednesený na mezinárodní lingvistické konferenci v Kodani v roce 1936, vzbudil značný ohlas (Jedlička, 1982, s. 272) a dal podnět k dalšímu bádání v této oblasti. Zásadním způsobem ovlivnil vnímání otázek normy zejména ve slovanských jazycích, především v polštině (Kurkowska, Buttler, Satkiewicz, Lubas'), ruštině (Barnet, Skvorcov) a slovinštině (Filin, Gorškov), ale také španělštině (Coseriu), němčině (Gloy, Hartung, Schmidt, Stich) (srov. Jedlička, 1982, s. 272-281) a francouzštině (Dubois) (srov. Koníčková, 2015, s. 10-11). Není předmětem této práce zabývat se podobnostmi a rozdíly $\mathrm{v}$ pojetí jazykové normy v širším mezinárodním kontextu, zaměříme se však více na oblast anglosaskou, a to zejména na úlohu normy ve výuce angličtiny jako druhého a/ nebo cizího jazyka.

\section{Pojetí jazykové normy ve výuce angličtiny}

Ve výuce cizích jazyků, zejména angličtiny, se na chyby tradičně pohlíží jako na odchylky od správné podoby jazyka, tedy od jazykové normy. Vymezení pojmu norma však, jak již bylo zmíněno, s sebou nese stejná úskalí jako 
vymezení pojmu chyba (srov. Allwright \& Bailey, 1991, s. 84; Ondráková, 2014, s. 11). Tradičně bývá za normu považován jazyk rodilých mluvčích cílového jazyka (L2), tedy norma rodilého mluvčího (native speaker norm; Allwright \& Bailey, 1991, s. 84). Toto pojetí však vyvolává další otázky - zejména, která z početných existujících variet cílového jazyka má být považována za správnou. Do chápání normy se rovněž promítá vývoj jazyka, především posun $\mathrm{k}$ méně formálnímu vyjadřování, které je více otevřené hovorovějším tvarům a jevům, jež byly dříve považovány za chybné a odchylující se od normy.

Situace je dále znesnadněna tím, že se postavení angličtiny ve světě přibližně od 80. let 20. století významně mění. Dochází zejména ke změně poměru $\mathrm{v}$ počtech rodilých mluvčích angličtiny a mluvčích, kteří ji užívají jako druhý nebo cizí jazyk. Zatímco ještě v polovině minulého století byla většina anglicky hovořících současně rodilými mluvčími angličtiny, odhaduje se, že na přelomu tisíciletí byl „poměr rodilých $\mathrm{k}$ nerodilým mluvčím přibližně 1 : 3“ (Crystal, 2003, s. 69). Lze předpokládat, že se v souvislosti s vyšším nárůstem obyvatelstva $\mathrm{v}$ zemích, kde je angličtina druhým a cizím jazykem, tento poměr dále zvyšuje v neprospěch rodilých mluvčích. Přehledně situaci rozšíření mluvčích angličtiny znázorňuje ve svém kruhovém modelu Kachru (1985, s. 11-30). Jeho model zůstává, i přes určité zjednodušující pojetí, nejvlivnější a v odborné literatuře často citovaný, proto z něho budeme vycházet i v tomto textu.

Kachru volí geograficko-historické hledisko, podle něhož zachycuje mluvčí angličtiny ve třech soustředných kruzích. Vnitřní kruh (inner circle) tvoří mluvčí z Velké Británie, USA, Kanady, Austrálie a Nového Zélandu, tedy zemí, $\mathrm{v}$ nichž je angličtina mateřským jazykem (English as a native language - ENL) převážné většiny obyvatel (Kachru, 1985, s. 12). Z hlediska normy jde o oblast, v níž se norma vytváří (norm providing circle). Vnější kruh (outer circle) představují země jako je Indie, Pákistán, Malajsie, Singapur, Keňa a mnohé další, zpravidla bývalé britské kolonie, $\mathrm{v}$ nichž se angličtina používá jako druhý jazyk, jazyk úřední a často také jako jazyk vyučovací (English as a second language - ESL; Walker, 2010, s. 3). Pokud jde o normu, je to oblast, v níž dochází k rozvoji normy (norm developing circle). Rozšiřující se kruh (expanding circle) pak představují země, v nichž se angličtina vyučuje jako cizí jazyk, ale nemá zde žádný oficiální statut (English as a foreign language - EFL), například Čína, Rusko, Japonsko, Brazílie, ČR, SR a jiné. Z hlediska normy jde o oblast na normě závislou (norm depending circle). I přes jisté nedostatky, kterých si autor byl vědom (Kachru, 1985, s. 14), zejména skutečnost, že 
tento model nereflektuje tzv. šedé zóny na pomezí jednotlivých kruhů, nebere v úvahu bilingvní mluvčí a mluvčí více jazyků, rodilé mluvčí žijící mimo vnitřní kruh, nerespektuje rozdíly a lingvistickou pestrost mezi jednotlivými zeměmi a implikuje jistou nadřazenost mluvčích ve vnitřním kruhu, je pro svou přehlednost a srozumitelnost stále využíván.

V současnosti, kdy angličtina $\mathrm{v}$ podstatně větší míře slouží ke komunikaci mezi nerodilými mluvčími, se však hranice mezi jednotlivými kruhy stírají a tradiční terminologické rozlišení na rodilé mluvčí a mluvčí, kteří používají angličtinu jako druhý nebo cizí jazyk, pozbývá smysl (Graddol, 2006, s. 110). Angličtina se ocitá v bezprecedentní situaci nesrovnatelné s jinými jazyky a stává se jazykem, který formují jak jeho rodilí, tak nerodilí mluvčí (Seidlhofer, 2011, s. 6).

Přetrvává však otázka, jakou normu zvolit pro výuku angličtiny jako druhého nebo cizího jazyka, zda normu rodilého mluvčího (native speaker norm), nebo normu, pro kterou se ustálilo označení angličtina jako lingua franca (English as a lingua franca - ELF).

\section{Norma rodilého mluvčího}

Tradiční a nadále často také jedinou normou ve výuce angličtiny je norma rodilého mluvčího (native speaker norm), tedy standardní varianta angličtiny tak, jak ji používají vzdělaní rodilí mluvčí ze zemí vnitřního kruhu, zejména Velké Británie a USA. Model rodilého mluvčího je považován za ideál, kterému se učící snaží přiblížit, a navzdory narůstajícím pochybnostem o jeho legitimnosti přetrvává jako model preferovaný (srov. např. Kirkpatrick, 2006; Smolder, 2009).

Norma rodilého mluvčího se však z mnoha důvodů jeví jako problematická, zejména proto, že není zcela jasné, která z existujících variant angličtiny by měla fungovat jako referenční. Přibližně od 80 . let 20. století probíhá mezi lingvisty diskuse o tzv. světových angličtinách (World Englishes). Ta se zaměřuje zejména na otázky svébytnosti různých variant angličtiny, a to nejen v rámci zemí vnitřního kruhu, např. britské, americké, australské, kanadské nebo irské angličtiny, ale i variant angličtiny v post-koloniálních, často multilingválních zemích vnějšího kruhu, např. indické, ghanské, nigerijské angličtiny (srov. např. Jenkins, 2003, 2007; Seidlhofer, 2011). 0 významu a aktuálnosti této debaty svědčí i fakt, že existuje stejnojmenný odborný časopis, Světové angličtiny (World Englishes), který odborníkům poskytuje publikační platformu. 
Tato situace pochopitelně nachází odraz i ve výuce angličtiny v zemích rozšiřujícího se kruhu, kde se diskutuje o tom, zda je model rodilého mluvčího i nadále jediným vhodným. Podle názoru některých odborníků je model rodilého mluvčího překonán, zvláště proto, že „počet mluvčích angličtiny, pro které je angličtina jazykem mateřským, je ve srovnání s celosvětovým počtem mluvčích angličtiny v menšině, je stále méně pravděpodobné, že ENL bude tvořit jazykovou normu" (Seidlhofer, 2011, s. 7). Tito odborníci pak propagují novou normu pro výuku angličtiny, angličtinu jako lingua franca (English as a lingua franca - ELF).

\section{Angličtina jako lingua franca}

Je obecně známou skutečností, že přibližně od poloviny 20. století se postavení, které angličtina zaujímá mezi ostatními jazyky, podstatně mění. Není již pouze mateřským jazykem mluvčích ze zemí vnitřního kruhu a úředním jazykem mluvčích ze zemí rozšiřujícího se kruhu, ale plní i roli společného celosvětově používaného dorozumívacího jazyka a stává se mezinárodním jazykem globální komunikace. Podle odhadů až 80 \% komunikace v angličtině probíhá mezi nerodilými mluvčími s různými mateřskými jazyky, pro které je angličtina druhý nebo cizí jazyk (srov. napřr. Crystal, 2003; Seidlhofer, 2004). Takto používaná angličtina je nazývána angličtina jako lingua franca - ELF.

V raném pojetí je ELF definována jako kontaktní jazyk, který si ke své komunikaci volí nerodilí mluvčí angličtiny, kteří nesdílí ani společný mateřský jazyk, ani kulturu (srov. Samarin, 1987; Firth, 1996; House, 1999, cit. podle Seidlhofer, 2011, s. 7). Seidlhoferová definuje ELF jako „jakékoliv použití angličtiny mluvčími různých mateřských jazyků, pro něž je angličtina zvoleným a často jediným možným nástrojem komunikace“ (2011, s. 7). Ani rodilí mluvčí angličtiny ze zemí vnitřního a vnějšího kruhu nejsou z komunikace v ELF vyloučeni (Jenkins, 2007, s. 2). Podobně Walker chápe ELF především jako „komunikaci mezi nerodilými mluvčími“, přestože z ní rodilí mluvčí angličtiny nemusí být nutně vyloučeni, ovšem za předpokladu, že respektují normy ELF (2010, s. 6-7). Navzdory tomu, že se o ELF v odborných kruzích intenzivně diskutuje, nenachází tato skutečnost prozatím odraz ve výuce angličtiny (Seidlhofer, 2004, s. 209) a nemá žádný skutečný dopad na tvorbu sylabu a výukových materiálů (Seidlhofer, 2011, s. 9).

Na nutnost konceptuální změny v otázce normy ve výuce angličtiny upozorňuje zejména Seidlhoferová, která poukazuje na neudržitelnost stávajícího modelu rodilého mluvčího jako jediného referenčního modelu pro výuku 
angličtiny. Vedle důvodů zmíněných výše uvádí zejména tu skutečnost, že došlo k zásadní proměně cíle výuky angličtiny. Tím již většinou není získání schopnosti komunikovat s rodilými mluvčími, pro něž by byl model rodilého mluvčího legitimní volbou, ale nejdůležitější je úspěšná komunikace s nerodilými mluvčími angličtiny. Je tedy namístě usilovat o nové pojetí pojmu kompetence a o uplatnění nové normy ELF pro výuku angličtiny (Seidlhofer, 2011, s. 17-18).

Vedle teoretických úvah o tom, proč je ELF vhodným modelem pro komunikaci v angličtině, je třeba vyjasnit, jaké charakteristiky tato nová varianta angličtiny má. Za tímto účelem vznikají korpusy ELF, v nichž je shromážděno rozsáhlé množství dat, která umožňují detailní popis ELF a dávají př́ležitost k jejímu zkoumání. Je to zejména rozsáhlý korpus mluvené angličtiny VOICE (Vienna-Oxford International Corpus of English), který tvoří přepisy 110 hodin autentických rozhovorů $v$ angličtině vedených mluvčími, jejichž mateřštinou, až na $7 \%$ rodilých mluvčích, není angličtina. Skutečnost, že tito mluvčí hovoří 50 různými mateřskými jazyky, nejen evropskými, poskytuje dostatečnou pestrost získaných dat (Seidlhofer, 2011, s. 23-24; Walker, 2010, s. 7). Podobně byl shromážděn korpus ACE - z dat získaných od mluvčích angličtiny pocházejících ze zemí sdružených v Asociaci národů jihovýchodní Asie (Walker, 2010, s. 7), korpus mluvené - ELFA - a psané - WrELFA - angličtiny jako lingua franca $v$ akademickém prostředí a korpus IST-Erasmus (Önen, 2015, s. 164).

Analýzou takto získaných dat bylo možné identifikovat hlavní znaky, v nichž se ELF liší od standardní normy rodilého mluvčího angličtiny v oblasti gramatiky a slovní zásoby takto:

Pro mluvčí ELF je charakteristické:

- používání stejného slovesného tvaru pro všechny osoby v př́ítomném čase prostém, vynechávání koncového -s ve 3. osobě jednotného čísla;

- nerozlišování mezi vztažnými zájmeny who pro osoby a which pro věci;

- vynechávání a/nebo chybné užívání určitého a neurčitého členu;

- užívání pravidelných tvarů množného čísla u podstatných jmen, které množné číslo tvoří nepravidelně, např. informations;

- užívání jednotného tvaru ukazovacího zájmena this používané i pro množné číslo; 
- používání sloves s obecným významem, např. do, have, způsobem, který není idiomatický.

(převzato a kráceno ze Seidlhofer, 2007, s. 92, cit. podle Walker, 2010, s. 8)

Z empirického výzkumu však vyplývá, že zatímco gramatika a slovní zásoba jsou jen zřídka příčinou nedorozumění mezi mluvčími ELF, odchylky od standardu rodilého mluvčího ve výslovnosti způsobují nedorozumění nejčastěji (Jenkins, 2000, cit. podle Walker, 2010, s. 26-27). Analýzou dat získaných z korpusů ELF bylo možné přesně popsat, které rysy výslovnosti byly nejvíce problematické, a ty tvoří oblasti, na něž je třeba zaměřit pozornost a zabránit tak nedorozumění při komunikaci. Tyto rysy tvoří tzv. jádro lingua franca (lingua franca core), a jsou to zejména výslovnost jednotlivých souhlásek a skupin souhlásek, především takových, které nemají ekvivalent $v$ mateřských jazycích mluvčích, např. /ð/ a / $\theta$ /, výslovnost samohlásek a větný př́izvuk (Walker, 2010, s. 25-47).

Definováním angličtiny jako lingua franca je vytvořen teoretický předpoklad $\mathrm{k}$ tomu, aby se mohla stát novou referenční normou pro výuku.

\section{Rozpolcení mezi normami}

Probíhající diskuse mezi experty o tom, která ze dvou výše zmíněných norem, ENL nebo ELF, je legitimní, bývá často poněkud vyhrocená. Odpůrci ELF, mezi něž patří např. Trudgill, Quirk a Görlach (Jenkins, 2007, s. 12), ji často zcela odmítají a označují za „lámanou, nedostatečnou a vadnou formu angličtiny" (Görlach, 2002, s. 12, cit. podle Seidlhofer, 2004, s. 228). Navzdory skutečnosti, že zastánci nové normy v podobě ELF mezi lingvisty jsou v menšině (Jenkins, 2007, s. 7), je zřejmé, že „jen málo seriózních vědců zabývajících se anglickým jazykem trvá na tom, že [...] pouze angličtina rodilých mluvčích je vhodným modelem pro všechny uživatele anglického jazyka" (Bambgbose, 1998, s. 1). Přesto však je model rodilého mluvčího nadále používán jako referenční, což při současném uznání norem nerodilých mluvčích vytváří značné napětí, které Bambgbose výstižně nazývá „rozpolcení mezi normami“ (torn between the norms) (1998).

Zdá se tedy, že jsme v posledních letech svědky přelomové situace, v níž proti tradičním zastáncům modelu normy rodilého mluvčího stojí ti, kteří usilují o uznání legitimnosti nové normy angličtiny jako lingua franca. Jejich cílem však není vytvoření jediného modelu, který by měl být plošně používán 
při výuce všech nerodilých mluvčích angličtiny, usilují spíše o vytvoření nového paradigmatu, $v$ němž by ELF našla rovnocenné místo vedle jiných uznaných forem angličtiny (World Englishes; Jenkins, 2007, s. 19-28).

\section{Pedagogické implikace}

Otázka volby normy je v cizojazyčné výuce velmi podstatná. Ve výuce angličtiny, která má oproti jiným jazykům v celosvětovém kontextu specifické postavení vzhledem $\mathrm{k}$ existenci různých norem, jako je angličtina rodilých mluvčích - ENL, angličtina jako druhý nebo cizí cizí jazyk - ESL/EFL, a angličtina jako lingua franca - ELF, je to otázka velmi komplexní. Situace je o to složitější, že, jak bylo výše zmíněno, mezi odborníky nepanuje v této oblasti shoda. Tradiční model rodilého mluvčího je zpochybňován, a to jak vzhledem k objemu komunikace $\mathrm{v}$ angličtině mezi nerodilými mluvčími, tak díky poznatkům korpusové lingvistiky, která poskytuje informace o autentickém jazyce, jenž se často liší od jazyka prezentovaného v učebnicích a výukových materiálech (srov. Carter \& McCarthy, 1997). Koncept angličtiny jako lingua franca, navzdory faktu, že je již dlouho předmětem výzkumu a zájmu odborníkủ, nenašel dosud jednotný odraz ve vzniku nové koncepce a hovoří se o mezeře v konceptualizaci (conceptual gap; Seidlhofer, 2004, 2011).

V této situaci jsou učitelé, a do jisté míry i žáci, konfrontováni s nelehkou volbou normy pro výuku. Jednou z cest, jak získat pohled na problematiku z pohledu praktické výuky, je podívat se, jak tuto otázku vnímají přímí aktéři výuky, žáci a učitelé. Postoje učitelů a žáků k volbě normy ve výuce angličtiny zkoumalo několik empirických výzkumů (zejména Timmis, 2002, s. 240). $\mathrm{Z}$ dotazníkového šetření, které se uskutečnilo v roce 2000 mezi účastníky z 45 zemí na konferenci IATEFL v Dublinu doplněného o 15 rozhovorů, vedených v Leedsu, vyplynulo, že $67 \%$ dotazovaných dává přednost normě rodilého mluvčího ve výslovnosti a $68 \%$ respondentů v gramatice (Timmis, 2002, s. 240-241). Podobné výsledky přinesly i studie uskutečněné v jiných zemích, např v Číně (Deyuan \& Qunying, 2010), Íránu (Jodai, Pirhadi, \& Taghavi, 2014) a ČR (Kalová, 2017). Norma rodilého mluvčího se tedy jeví i nadále jako legitimní pro výuku angličtiny jako druhého a/nebo cizího jazyka. Navzdory těmto závěrům zůstává norma rodilého mluvčího jedinou oficiálně doporučenou normou pro výuku angličtiny v Evropě, jak bude popsáno v následující kapitole. 


\section{Norma a jazyková politika}

Klíčovým oficiálním dokumentem, který se snaží poskytnout státům Evropy jednotná základní kritéria pro cizojazyčnou výuku, je Společný evropský referenční rámec pro jazyky - SERRJ. Tento politický dokument, vytvořený Radou Evropy, se snaží mimo jiné obecně vymezit cíle, úkoly a funkce cizojazyčné výuky, popsat úrovně ovládání jazyka pomocí jasně stanovených deskriptorů a způsoby, jak nejlépe cílů výuky dosáhnout. Nechává však značnou volnost pro konkrétní aplikaci těchto principů a nestraní žádné teorii. Otázky normy nejsou v tomto dokumentu explicitně definovány, $\mathrm{v}$ textu se k nim však odkazuje, např. ve vztahu k chybám ve výslovnosti, „kdy se [studenti] těsně přiblížili normám cílového jazyka" (Ivanová et al., 2002, s. 135). Lze tedy vyvodit, že se za normu považuje norma rodilého mluvčího, čemuž odpovídá i část věnovaná chybám (Ivanová et al., 2002, s. 157-158). To může vycházet i ze skutečnosti, že se dokument snaží postihnout veškerou cizojazyčnou výuku, a není proto možné zohlednit v něm zvláštní postavení angličtiny. Na druhou stranu je hlavním cílem jazykového vzdělávání, deklarovaném v tomto dokumentu, vícejazyčnost, která je pojímána jako schopnost budovat komunikační kompetenci, „ke které přispívají všechny znalosti a zkušenosti s jazykem a ve které jsou všechny jazyky usouvztažněny a navzájem se ovlivňují" (Ivanová et al., 2002, s. 4). To by tedy naznačovalo, že norma ELF pro výuku angličtiny není vyloučena.

Volba normy pro cizojazyčnou výuku není jasně definována ani v českém kontextu. Rámcový vzdělávací program - RVP - je oficiální kurikulární dokument, který vymezuje vzdělávání jako celek, konkrétně definuje závazné rámce pro jednotlivé etapy vzdělávání a upřesňuje dovednosti, kterých by žáci měli dosáhnout po absolvování jednotlivých typů škol, tzv. očekávané výstupy. Jazyková norma pro výuku cizích jazyků není explicitně stanovena, je však zřejmé, že se předpokládá použití normy rodilého mluvčího. V oblasti produktivních řečových dovedností v cizojazyčné výuce pro gymnázia je např jako jeden z cílů stanoveno, že „žák formuluje svůj názor srozumitelně, gramaticky správně, spontánně a plynule“ (Balada et al., 2007, s. 17), takže aplikovaná norma je pravděpodobně norma rodilého mluvčího. V učebních osnovách ZŠ pro základní školy v části Jazykové prostředky - anglický jazyk je výslovně zmíněna norma rodilého mluvčího, a to varianta britské angličtiny:

Vzhledem ke svému širokému použití má angličtina mnoho zeměpisných variant, a proto je důležité, aby se žáci postupně receptivně seznamovali s co nejpřesnějším vzorkem mluveného i psaného jazyka. Pro aktivní ovládání bude u druhého cizího jazyka sloužit, pokud jde o nahrávky, model britský. (MŠMT, 1996, s. 17, 56) 
Je tedy zřejmé, že otázce normy v cizojazyčné výuce není v obecných oficiálních dokumentech věnována explicitní pozornost. Je však implikováno, že se jedná o normu rodilého mluvčího. $V$ konkrétních osnovách pro výuku se potom objevuje jako norma model rodilého mluvčího, a to britského.

Stanovení normy, s níž srovnáváme výkony žáků, je úzce spojeno s klasifikací chyb, nebot' ta může výrazně napomoci k jednoznačnějšímu pojetí chyb a jejich úlohy ve výuce. Právě na ni se proto zaměříme v následující části textu.

\subsection{Klasifikace chyb}

Hlavními kritérii pro dělení chyb jsou zpravidla jejich závažnost, přínos pro učení, příćiny a okolnosti jejich vzniku, kontext, v němž vznikají, možnosti práce s chybou, zejména otázky korektivní zpětné vazby a v neposlední řadě diagnostická role chyb.

V českém prostředí se problematikou chyby z psychologického hlediska zabýval především Kulič, a to zejména v díle Chyba a učení (1971), v němž podrobně zkoumal funkci chybného výkonu $v$ učení a $v$ jeho řízení. Na základě podrobné analýzy modelů učení zkoumal možnosti regulace učení prostřednictvím chyby, chybný výkon charakterizoval jako produkt i faktor ovlivňující učení (Kulič, 1971, s. 65). Na základě studia starších pramenů rozlišoval Kulič dvě základní kategorie chyb. Jsou to na jedné straně chyby, jejichž působení má při správném přístupu na učení pozitivní vliv, chyby označované jako „oprávněné, dobré, smysluplné, kognitivní, poučné, běžné“, a naproti tomu chyby označované jako „úplné, smysluprosté, nesmyslné, bezvýznamné, nekognitivní, hloupé, neinstruktivní, smrtelné" (Kulič, 1971, s. 94). Jakkoliv se toto dělení může z dnešního pohledu jevit jako překonané, byl Kulič patrně jedním z prvních, kdo v českém kontextu upozornil na to, že chybný výkon může pozitivně přispívat $\mathrm{k}$ učení. Podstatným přínosem bylo zejména stanovení podmínek, za nichž k tomu dochází. Podrobněji o nich bude pojednáno v části 3.1 zaměřující se na práci s chybami.

Zejména v oblasti cizojazyčné výuky se vžila kategorizace chyb z hlediska jejich závažnosti a příčin vzniku. Anglická terminologie nabízí pro český termín chyba více významově odlišných ekvivalentů. Např́íklad Corder (1981, s. 10-11) rozlišuje error, mistake a lapse. Nesystematické chyby - mistakes chyby performance, jsou chyby, kterých se dopouštějí jak studenti cizího jazyka, tak rodilí mluvčí. Výraz mistake je vnímán jako přeřeknutí či přepsání způsobené spíš nepozorností než neznalostí. Jde o omyl, který je žák schopen 
sám opravit, a to bud' zcela bez upozornění na to, že se ho dopustil, případně po náznaku od učitele či spolužáků, „,rodilí mluvčí se dopouštějí chyb - mistakes - neustále, přestože správnou formu obvykle znají" (Gower, Walters, \& Phillips, 1995, s. 164). Chyba, ke které dochází pod vlivem řady vnějších faktorů, např́klad únavy, stresu, výpadku paměti, silných citových pohnutek apod., bývá nazývána lapse, a rovněž se vyskytuje jak v jazyce prvním, mateřském, tak v jazyce cílovém. Naproti tomu errors jsou závažné systematické chyby, k nimž dochází u žáků při studiu cizího jazyka. Jde o chyby kompetence, student si mnohdy není vědom, že se takové chyby dopustil, a často se domnívá, že jeho vyjádření je zcela správné. Správnou formu zpravidla nezná nebo ji není schopen vhodně použít (srov. Corder, 1981, s. 10-11; Ondráková, 2014, s. 17). Podobně Edge (1989, s. 7-11) zmiňuje kromě errors, které vymezuje podobně jako Corder, také attempts - pokusy, které vnímá jako snahu žáků o vyjádření něčeho, co doposud systematicky nestudovali, tudíž neznají správnou jazykovou podobu, a přesto se snaží, většinou na základě dosavadní znalosti, dosáhnout sdělení významu (Edge, 1989, s. 10-11). Rozlišení errors a mistakes má význam z hlediska didaktiky cizího jazyka, a přestože se $\mathrm{v}$ české terminologii explicitně objevuje méně často, v pedagogické praxi se s ním v českém kontextu běžně setkáváme.

Závažnost však není jediným kritériem třídění chyb. Choděra například zmiňuje tři hlavní kritéria dělení, a to vedle závažnosti také jazykový status a př́ičiny vzniku. Podle závažnosti dělí chyby na velké (hrubé), střední a malé, bere $\mathrm{v}$ úvahu rovněž jazykový status - lingvistický aspekt, podle něhož dělí chyby na lexikální, gramatické, pravopisné, fonetické, a dále aspekt psychologický, tedy příčiny vzniku chyb, do této kategorie řadí nejrůznější aspekty, od chybné generalizace a analogie až po chyby způsobené vnějšími vlivy, stresem, nepozorností apod. (Choděra, 2013, s. 163-164).

Zatímco kategorizace chyb v českém pojetí se v mnoha ohledech shoduje $\mathrm{s}$ přístupem zahraničním, $\mathrm{v}$ otázce př́nosu chyb pro výuku taková shoda není jednoznačná.

Zejména Choděra odmítá přijmout chybu v cizojazyčné výuce jako př́iležitost $\mathrm{k}$ učení. S odkazem na pojet typické pro audiolingvální přístup (podrobněji viz 2.2), v zahraničí považované již od 70. let za překonané (srov. např. Richards \& Rodgers, 2001, s. 72-73), považuje chybu za „učební neúspěch" a tvrdí, že „,je třeba výskyt chyb předvídat [...] a podle možností minimalizovat“ (2001, s. 113). Tato „minimalizace chyb“ se týká i využití 
chyby ve výukových materiálech, což Choděra kategoricky zavrhuje a požaduje rovněž, poněkud nerealisticky, aby se chyb nedopouštěl ani učitel:

Konečně platí zlaté pravidlo zkušených učitelů cizího jazyka: z úst pedagoga (a také z textu učebnice - dodejme my) nikdy nesmí zaznít jazyková chyba. Žák musí mít totiž vždy pocit, že to co je dáno v učebnici nebo řekne učitel, je spolehlivě správné, zaručené, a tedy vhodné $\mathrm{k}$ napodobování, bezpečnému následování. (2001, s. 37)

Choděrův názor na roli chyb v cizojazyčné výuce sdílí do jisté míry i jiní čeští autoři, např. Hendrich (1988, s. 373). Je pozoruhodné, že ti autoři, kteří se v českém kontextu zaměřují na úlohu chyb v učení obecně, např. Kulič (1971), nebo v jiných oborech než cizojazyčná výuka, např. Slavík ve výtvarné výchově $(1994,1999)$ a Hejný v matematice (2001), v souladu s poznatky ze zahraniční literatury zdůrazňují pozitivní dopad práce s chybou na výuku. Zdá se tedy, že se do jisté míry projevuje relativní nedostatek relevantních českých zdrojů v oblasti didaktiky cizích jazyků, které se na problematiku chyby v cizojazyčné výuce zaměřují. Zvláště v posledních letech ale zájem o tuto problematiku stoupá (např. Ondráková, 2014). V tomto textu se přínosu chyby pro výuku budeme detailněji věnovat ve třetí části.

Otázky definice, klasifikace a vnímání role chyb v učení jsou velmi podstatnou charakteristikou jednotlivých metod a přístupů uplatňovaných v procesu cizojazyčné výuky a výstižně ilustrují rozdíly mezi nimi. Podrobněji se na ně zaměříme v následující části, která se snaží nastínit, jak se úloha chyby $v$ historii proměňovala.

\section{2 Úloha chyb v cizojazyčné výuce $\mathrm{v}$ diachronní perspektivě}

Metody výuky jakéhokoliv oboru jsou zpravidla založeny na kombinaci poznatků o oboru samotném, poznatků z pedagogické psychologie a teorie učení. Nezastupitelnou úlohu zde hrají oborové a předmětové didaktiky, které působí jako „disciplíny situované mezi určitý vědecký, umělecký, technický či jiný obor a vědy o výchově a vzdělávání“ (Janík \& Stuchlíková, 2010, s. 8), a tím propojují obecnou teorii vědeckého zkoumání s konkrétní pedagogickou praxí. Nejinak je tomu i v cizojazyčné výuce, jejíž různé metody a př́stupy vycházejí z analýzy a aplikace lingvistických poznatků o jazyce a modelů osvojování jazyka spolu s psychologickými poznatky teorií učení. 
Rozdíly mezi jednotlivými metodami a přístupy k učení se mimo jiné projevují v práci s chybou ve výuce cizího jazyka, a právě na ní se pokusíme ilustrovat odlišnosti mezi nimi. ${ }^{3}$

\subsection{Gramaticko-překladová metoda}

Nejstarší metodou, která od středověku přibližně do poloviny 20. století dominovala ve výuce klasických i moderních cizích jazyků, je metoda gramaticko-překladová (srov. napřr. Richards \& Rodgers, 2001, s. 5). Situace v českých zemích a na Slovensku, a patrně i v jiných postkomunistických zemích, byla ze zřejmých politických důvodů jiná, gramaticko-překladová metoda tu proto ve výuce cizích jazyků převažovala až do 80 . let 20. století (Hanušová, 2003, s. 17) a v mnohých zemích je oblíbená dodnes. Tato metoda však nemá oporu v teorii jazyka a jen ojediněle využívá poznatků psychologie a pedagogiky. Klade velký důraz na přesnost a bezchybnost. ,Je považováno za velmi důležité, aby studenti dokázali správně odpovědět." (Larsen-Freeman, 2000, s. 19).

Se vzrůstajícím zájmem o mluvenou podobu jazyka, dále v souvislosti se vznikající fonetikou a potřebou komunikovat v cílovém jazyce, narůstá od 80. let 19. století kritika gramaticko-překladové metody a snaha o vytvoření efektivnějšího způsobu učení (srov. Richards \& Rodgers, 2001).

3 V následujícím textu se budou opakovaně objevovat termíny metoda a př́stup. Pojetí těchto dvou klíčových termínů je, v souladu s Rodgersem a Richardsem, chápáno následovně: př́stup (approach) je vnímán jako „soustava teorií a domněnek o povaze jazyka, učení se jazyku a od toho odvozených principů pro vyučování jazyka“, které však rozhodně nenabízejí konkrétní a detailní pokyny a postupy, které mají být ve výuce použity, ale jde spíše o „řadu interpretací, jak lze tyto principy aplikovat" (Richards \& Rodgers, 2001, s. 20). Mezi př́ístupy řadí Richards a Rodgers například komunikační přístup, kooperativní učení, mnohočetné inteligence, neurolingvistické programování, přirozený přístup, celostní jazyk a podobně. Naproti tomu metoda (method) nabízí „systém založený na určité teorii jazyka a učení [...] s podrobným vymezením obsahu, rolí učitelů a žáků, učebních postupů a technik." Učitelé byli vyškoleni k užívání určité metody a jejich úkolem bylo „ř́́dit se metodou a aplikovat ji přesně podle pokynů“ (Richards \& Rodgers, 2001, s. 19). Na tomto místě je rovněž třeba zmínit odlišné chápání pojmu metoda v české a německé odborné literatuře, kde je vnímáno v užším slova smyslu jako „význačný specifický způsob činnosti učitele a žáka, jímž si žák za vedení učitele osvojuje vědomosti, dovednosti a návyky, rozvíjí své schopnosti," a vedle toho $\mathrm{v}$ širším slova smyslu jako „globální, generální přístup k vyučování-učení cizímu jazyku, základní lingvodidaktická doktrína, metodický směr", u Františka Malíře nazývaný „koncepce“ (Choděra, 2013, s. 92). 


\subsection{Metody prímé}

Reformní hnutí z přelomu 19. a 20. století vedlo ke vzniku takzvaných přirozených metod výuky cizích jazyků, pro které se vžil souhrnný termín př́mé metody. Ty se dostávají do popředí od počátku 20. století a kulminují v 50. až 70. letech. Řadíme k nim nejen př́ímou metodu v užším slova smyslu, ale rovněž metodu Berlitzovu, armádní metodu, SLT (situational language teaching), a především metodu audiolingvální. Tyto metody shodně kladou důraz na mluvenou podobu jazyka, snaží se eliminovat mateřský jazyk a co nejvíce používat jazyk cílový. Jde o metody zaměřené na učitele, aktivní role žáka je záměrně potlačena - „žák nemá žádnou kontrolu nad obsahem učení [...] tempo udává učitel" (Richards \& Rodgers, 2001, s. 43). Ve výuce se pomocí drilů a opakování usiluje o minimalizaci chyb a přesnost vyjadřování (srov. Brown, 2001, s. 22; Richards \& Rodgers, 2001, s. 53).

\section{Behaviorální model osvojování a hypotéza kontrastivní analýzy}

Audiolingvální metoda byla pevně ukotvena v teorii a využívala poznatky strukturalismu a kontrastivní analýzy v oblasti teorie jazyka a behaviorismu v rovině psychologické. Pro toto období je typické vnímání „jazyka žáků jako nesprávné podoby jazyka cílového" (Lightbown \& Spada, 2013, s. 41). Skinner (1957, cit. podle Lightbown \& Spada, 2013, s. 15), zakladatel teorie programovaného učení, propaguje na základě výsledků svých laboratorních pokusů teorii, že je třeba $\mathrm{v}$ učení upevňovat dobré návyky a formovat tak správné - tedy bezchybné - cílové jednání. $V$ této snaze o upevnění usiluje o to, aby odpovědi byly díky vysokému stupni řízení pomocí stimulů a nápovědy pokud možno bezchybné (Kulič, 1971, s. 30-31; Choděra, 2013, s. 163).

Pro toto období je charakteristická hypotéza kontrastivní analýzy (contrastive analysis hypothesis - CA), jejímž průkopníkem a autorem stěžejního díla Linguistics across cultures (Lingvistika napříc kulturami) byl Lado (1957). V souladu se zásadami strukturalismu se zaměřuje zejména na systematické srovnávání L1 a L2, a to izolovaným popisem a srovnáváním jazykových systémů, zejména fonologického, morfologického, syntaktického a jen omezeně lexikálního, a kladením důrazu na formu, nikoliv na význam (Saville-Troike, 2006, s. 34-35). Za stěžejní je považován vliv mateřského jazyka, který je vnímán jako klíčový aspekt procesu osvojování. Předpokládá se, že jevy, které jsou formou, významem a četností výskytu podobné v L1 a L2, jsou osvojovány snáze a rychleji. Toto působení L1, které usnadňuje osvojování L2, se nazývá pozitivní transfer. 
Chyby, kterých se žáci při osvojování L2 dopouštějí, jsou rovněž vysvětlovány působením mateřského jazyka. Toto působení je vnímáno především jako nežádoucí jev, který osvojování ovlivňuje negativně - negativní transfer. Chyba je vnímána jako selhání, kterému je třeba zabránit. Na osvojování je, v souladu s behaviorální psychologickou teorií, nahlíženo jako na mechanický proces formování správných návykủ. Tento přístup byl v následujícím období podroben kritice - zejména pod vlivem Chomského a Cordera, kteří poukazují mimo jiné na tu skutečnost, že žáci se mnohých z chyb předvídaných na základě poznatků CA nedopouštějí, dopouštějí se však jiných, jejichž výskyt nebyl předpokládán. Často rovněž nedochází k očekávanému pozitivnímu transferu, tedy snazšímu osvojování těch forem L2, které mají ekvivalent v L1 (Saville-Troike, 2006, s. 37).

Přestože kontrastivní analýza nenabízí uspokojivé vysvětlení vzniku chyb a procesů osvojování cizího jazyka vůbec (Ellis \& Barkhuizen, 2005, s. 52), otázky vlivu L1 na osvojování L2 zůstávají nadále v jádru pozornosti výzkumu SLA (Ellis, 1994a, s. 29; Saville-Troike, 2006, s. 34).

\section{Přínos prímých metod}

Přestože přímé metody vykazují jisté dílčí odlišnosti, spojuje je požadavek redukovat chyby a soustředit se na přesné vyjadřování: „studenti zřídka používají jazyk spontánně. Učitelé brání začátečníkům mluvit volně z obavy, že jim to umožní dopouštět se chyb. Tyto chyby by se mohly stát návyky. Je tedy lepší těmto špatným zvykům zabránit dříve, než k nim dojde" (Lightbown \& Spada, 2013, s. 155). Drily, modelové dialogy a opakování, které jsou hlavní technikou používanou v rámci audiolingvální metody, si kladou za cíl minimalizaci chyb. Interakce mezi žáky není podporována, nebot' právě ta by mohla vést ke vzniku chyb, kterým je však potřeba za každou cenu zabránit. Velký důraz je kladen na správnou výslovnost, prŕízvuk, rytmus a intonaci, jakož i na gramatickou správnost. Přesnost vyjadřování je primárním cílem. Jakkoliv přímé metody vzbudily ve svých počátcích velká očekávání, ne vždy se podařilo je naplnit, nebot' žáci nebyli schopni drilované struktury použít $\mathrm{v}$ reálných situacích a při volném jazykovém projevu. Kritika, která se začala objevovat již v průběhu 60 . let 20 . století, rovněž zpochybnila teoretické základy př́mých metod, a to jak v teorii jazyka - strukturalismu, tak v teorii učení a osvojování jazyka - behaviorismu. „Bylo to právě časté selhávání tradiční gramaticko-překladové a audiolingvální metody při vytváření plynulosti a přesnosti u studujících cizího jazyka, které vedlo k rozvoji na komunikaci více zaměřených přístupů k učení." (Lightbown \& Spada, 2013, s. 156). 


\subsection{Komunikační prístup}

S vývojem poznání o jazyce, zejména v díle Chomského, tvůrce principu generativní transformační gramatiky, dochází postupně k odmítnutí strukturalistického př́istupu k pojetí jazyka a k nástupu kognitivismu. Díky novým poznatkům z oblasti psychologie, antropologie a neurověd je rovněž podroben kritice a posléze odmítnut behaviorální přístup v teorii osvojování jazyka. Nově vznikající komunikační přístup v 70. až 80 . letech 20 . století, v českých zemích aplikovaný ve větší míře až od počátku 90. let, přináší tedy zcela zásadní změnu paradigmatu didaktiky cizích jazyků.

Kognitivní model osvojování, chybová analýza a teorie mezijazyka

Kognitivismus 60.-70. let 20. století přináší některé změny v pohledu na procesy ovlivňující SLA. Zaměříme se zejména na to, jak nahlíží na úlohu, kterou hrají chyby v cizojazyčné výuce.

Kontrastivní analýzu, typickou pro behaviorální model osvojování cizího jazyka, nahrazuje chybová analýza (error analysis - EA), která se stala jádrem výzkumu SLA (Ellis \& Barkhuizen, 2005, s. 52). Na rozdíl od kontrastivní analýzy se chybová analýza zaměřuje na skutečné chyby žáků, nikoliv na ty, jejichž výskyt se předpokládá v teoretické rovině (Saville-Troike, 2006, s. 37). Od povrchových jevů v jazyce, jejichž zkoumáním se v souladu s lingvistickou teorií strukturalismu zabývala kontrastivní analýza, se pozornost přesouvá na hlubší principy ovlivněné vrozenými dispozicemi, jak je formuluje Chomsky (např. 2007, s. 180-194). Ve snaze o porozumění procesům osvojování jsou chyby podrobně studovány, klasifikovány a jsou zkoumány jejich příčiny. To vede ke zformování hypotézy o existenci přechodného stadia vývoje žákovského jazyka na cestě od jazyka mateřského $\mathrm{k}$ jazyku druhému nebo cizímu, vzniku teorie mezijazyka (interlanguage hypothesis; Selinker, 1972; Corder, 1981). Chyby již nejsou vnímány jako jev, kterému je třeba pokud možno předcházet a zabránit, ale jako významný rys přechodného vývojového stadia s velkou vypovídací hodnotou přinášející poznatky o tom, jak probíhá osvojování. Prostřednictvím chyb, které jsou přirozenou a nevyhnutelnou součástí procesu osvojování, si žák „testuje své hypotézy o povaze jazyka, který se učí (Corder, 1967, cit. podle Saville-Troike, 2006, s. 39). Žákovský jazyk je vnímán jako svébytný, na L1 a L2 nezávisle existující systém, který se stává předmětem zkoumání SLA. 


\section{Přínos chybové analýzy a teorie mezijazyka}

Chybová analýza a teorie mezijazyka mají svůj význam při odhalování principů osvojování L2, a to i přes určité neshody panující zejména v oblasti normy, ke které má být vztahován pokrok žáků při osvojování L2. Jazyková produkce, která se blíží produkci rodilých mluvčích, není mnohdy z celé řady mimojazykových důvodů, například politických či náboženských, žádoucí (srov. např. Saville-Troike, 2006, s. 43; Ondráková, 2014, s. 12-15). EA je významným stadiem vývoje zkoumání žákovského jazyka, přestože v mnoha ohledech jsou její výsledky problematické, což je způsobeno např. chybějící rigorózní klasifikací chyb, což neumožňuje replikovat některé výzkumy. Může však přinést cenné poznatky, zvláště při podrobné kvalitativní analýze žákovského jazyka (Ellis, 1994a, s. 20).

\section{Př́nos komunikačního př́stupu}

V širokém rámci komunikačního přístupu se objevuje celá řada nových metod, které přes mírné odlišnosti spojují četné aspekty, mimo jiné i způsob, jakým se vymezují vůči zásadní metodě předchozího období - metodě audiolingvální. Významně se mění mnoho aspektů charakteristických pro výuku cizích jazyků, což pramení z nového pojetí teorie jazyka i teorie učení. Důraz není nadále kladen na formální správnost a přesnost, ale spíše na plynulost vyjadřování. K učení dochází prostřednictvím interakce, s důrazem na co největší autentičnost: „Učit se jazyk znamená učit se komunikovat" (Finocchiaro \& Brumfit, 1983, cit. podle Richards \& Rodgers, 2001, s. 156). Pozornost se odklání od učitele a zaměřuje se na žáka, podstatná je nejen interakce mezi učitelem a žáky, ale i mezi žáky navzájem. Nově se objevuje polarita plynulosti a přesnosti (Brumfit, 1984, s. 50-57), což má zásadní dopad na pojetí jednotlivých činností ve výuce. $S$ tím souvisí zcela zásadní změna pojetí role chyby ve výuce, zaměření dané činnosti na plynulost nebo na přesnost ovlivňuje, zda a jakým způsobem bude chyba opravována a jak se s ní bude nadále pracovat. Chyby ztrácejí stigma selhání a oproti dřívějším přístupům jsou nově vnímány jako přirozená součást vývoje, přijímány jako znaky vývojových procesů (srov. Krashen, 1982, cit. podle Lightbown \& Spada, 2013, s. 106) a vítány jako příležitosti k dalšímu rozvoji. „Jazyk často vytváří jedinec metodou pokusu a omylu." (Finocchiaro \& Brumfit, 1983, s. 91, cit. podle Richards \& Rodgers, 2001, s. 157). Ve výuce se poprvé objevuje snaha o rovnoměrný rozvoj všech čtyř řečových dovedností, cílem se nově stává komunikační kompetence a s ní související plynulost vyjadřování. V pozdějším období je kladen důraz na vyváženost přesnosti a plynulosti. 


\subsection{Postkomunikační př́stup}

20. století přineslo celou řadu inovativních metod a přístupů, které v mnoha zemích zásadním způsobem zasáhly do výuky cizích jazyků, avšak postupně se začala projevovat určitá skepse. Stále jasněji vyvstávala omezení jednotlivých metod a přístupů a také malá šance na to, že by vývoj v oblasti didaktiky cizích jazyků $\mathrm{v}$ dohledné době přinesl nové, převratné postupy. V souvislosti s touto atmosférou hovoří někteří autoři o „smrti metod“ (Allwright \& Bailey, 1991), „období po metodách“ (srov. Kumaravadivelu, 2007), v české odborné literatuře se objevuje také označení „didaktický pluralismus" (Mothejzíková, 1995, s. 175). Existence jediné správné metody je zpochybňována (srov. Prabhu, 1990; Larsen-Freeman, 2000). V odborném diskurzu se postupně etabloval termín „post-metodické období“, pro které je příznačné, že rozhodnutí o vhodnosti metody a přístupu ve výuce ponechává na poučeném učiteli, který může nejlépe zvážit všechna kontextová specifika a kvalifikovaně rozhodnout o vhodném přístupu.

Mezi hlavní charakteristiky tohoto současného přístupu patří významné posílení autonomie a zodpovědnosti učitele i žáka, zásadní změna role učitele, který se stává spíše zprostředkovatelem a facilitátorem než zdrojem encyklopedických znalostí, a v neposlední řadě také nástup moderních technologií a internetu a jejich dopad na procesy učení (srov. např. Larsen-Freeman \& Anderson, 2011).

Podle Kumaravadivelu (2006, s. 59) dochází k jasně patrnému posunu zejména v těchto třech oblastech: „(a) od komunikačního přístupu v cizojazyčné výuce k výuce založené na plnění úkolů (task-based teaching), (b) od pedagogiky založené na metodách k pedagogice po metodách a (c) od systémového objevování ke kritické analýze diskurzu."

Podobně Brown shrnuje zásady, kterými by se současná pedagogika měla ubírat, aby došlo k úspěšnému osvojení jazyka „[současní učitelé] jsou méně náchylní k použití předchystané - a pravděpodobně neúčinné - metody učení a vyučování jazyka a jsou více ochotní $\mathrm{k}$ tomu, aby přímo reagovali na potřeby a cíle svých studentů" (2002, s. 17).

V rámci eklektického přístupu, ze kterého vycházíme, nebot' jde o převládající přístup typický pro současnou pedagogiku, jsou chyby vnímány v širším kontextu. Spíše než o jejich opravování hovoříme o poskytování korektivní zpětné vazby (corrective feedback - KZV). Podrobněji bude o současných 
názorech na KZV pojednáno dále, v kapitole 3.3. Opravování je jen jednou ze složek zpětné vazby, která má poskytovat vyvážené informace o výkonu žáka, tedy to, co bylo správné, i to, co nikoliv (srov. Ellis, 2009, s. 3 ; Ur, 2009, s. 242). V této práci se zaměříme zejména na negativní zpětnou vazbu, tedy nakládání s chybami. Pro zkoumání chyb je rovněž klíčová jejich kategorizace, o níž je podrobně pojednáno výše.

\subsection{Přesnost, plynulost a úloha chyb naprríc metodami}

Jak je patrné $\mathrm{z}$ výše uvedeného nástinu vývoje metod a přístupů v cizojazyčné výuce, úloha, kterou hrály přesnost, plynulost a postoj k chybám, je zřejmá. U klasické metody gramaticko-překladové a u metod př́mých, přestože jsou ve svých charakteristikách zcela odlišné, se koncept plynulosti neobjevuje takřka vůbec a hlavním cílem výuky je přesnost a bezchybnost. Zvolené metody výuky, překlad a drily, jsou natolik řízené, že k chybám takřka nedochází. S nástupem komunikačního přístupu, který klade důraz především na mluvenou podobu jazyka a komunikaci, se pozornost logicky přesouvá na opačný pól, tedy k plynulosti, a význam přesnosti, tak podstatný pro předchozí období, bývá zpochybňován, v extrémním výkladu se od opravování chyb zcela upouští. Postkomunikační období, v němž se nachází didaktika cizích jazyků nyní, se uchyluje k hledání rovnováhy a považuje plynulost a přesnost za rovnocenné, navzájem se doplňující aspekty. Přestože se podíl aktivit zaměřených na přesnost a plynulost mění v závislosti na různých faktorech, především na pokročilosti žáků, oba dva aspekty je potřeba při výuce cizího jazyka rozvíjet rovnoměrně. Je znovu uznán význam chyb a reakcí na ně pro učení a při správném přístupu jsou vnímány jako vítané přiležitostí k učení, napomáhající osvojování.

\section{Přístup k chybám a jejich přínos pro učení}

Z výše uvedeného přehledu vybraných metod výuky cizích jazyků a různého přístupu k chybám je patrné, že chyby hrají ve výuce významnou roli. Klíčové jsou především odpovědi na otázky, zda opravovat, pokud ano, $k d y$ k opravě přistoupit, co přesně opravovat a jak nejlépe opravovat (srov. Edge, 1989, s. 69; Sheen \& Ellis, 2011, s. 598-601). Vedle toho vyvstává rovněž otázka, kdo má opravu provést, zda opravovat vždy a všechny chyby (Gower et al., 1995, s. 167; Sheen \& Ellis, 2011, s. 598-601). Odpovědi na tyto otázky, které si při výuce každodenně klade každý učitel, nejsou snadné ani jednoznačné a při hledání vhodných způsobů je třeba zvažovat mnoho skutečností. 


\subsection{Práce s chybami}

V literatuře zabývající se dopadem chyb na proces učení se střetávají dva názory: na jedné straně je to vnímání chyb jako negativního faktoru, který proces učení ohrožuje a snižuje motivaci k učení - „chyba, prožívaná subjektem jako neúspěch, ohrožuje dynamicko-motivační stránku učení" (Kulič, 1971, s. 90), na druhé straně pak chyby vnímané jako povzbuzení k hledání nového, správného řešení, tedy „mobilizující funkce chyby“ (Kulič, 1971, s. 86). Kulič zmiňuje jako oblast, v níž se chyba poprvé vnímá jako „dobrá“, kognitivní, plnící korigující funkci, oblast učení řešením problémů (1971, s. 84).

K tomu, aby chyba měla na učení pozitivní dopad, je třeba splnit následující podmínky: chybu je nutné nejprve identifikovat v širším slova smyslu, tedy stanovit, že jde o chybný výkon - detekce, ale také v užším slova smyslu blíže určit charakter chyby - identifikace tak, aby nebyl ohrožen efekt učení. Chybný výkon je dále nutné interpretovat, a to jak směrem vzad, tedy pátrat po příčinách chyb, tak směrem vpřed, tedy předvídat chyby budoucí a předcházet jim. Neméně důležitá je korekce, čili vhodná zpětná vazba jako reakce na chybný výkon (srov. Kulič, 1971, s. 97-135). Přestože citovaná publikace staví zejména na poznatcích z oblasti přírodních věd, zvláště matematiky, biologie a fyziky, v obecné rovině jsou její závěry velmi př́nosné i pro výzkum role chyby obecně, tedy i ve výuce cizích jazyků, a vycházejí z ní další autoři zabývající se danou problematikou. V návaznosti na Kuličovy poznatky popisují Choděra a Ries jednotlivé fáze práce s chybou následovně (1999, s. 99):

Práce s chybami probíhá (nebo probíhat má) v těchto fázích spojených s jistými operacemi:

1) detekce chyby (registrování jejího výskytu);

2) identifikace chyby (fonetická, gramatická atd.);

3) interpretace příčin chyby (chybná analogie, nepozornost atd.);

4) korekce chyby (opravné zásahy, korekční cvičení);

5) prevence chyb (kontrainterferenční cvičení apod.).

Zejména ke korekci musí učitel přistupovat obezřetně, a to například při opravách ústního projevu, kdy by časté a nevhodné zásahy do žákova projevu mohly narušit proces učení. Obecně platí princip, že je vhodnější opravovat chyby performance bez odkladu a kompetenční chyby po pečlivém rozboru 
(Choděra \& Ries, 1999, s. 99), záleží však samozřejmě na konkrétních kontextových okolnostech, např. zaměření dané aktivity na přesnost nebo plynulost projevu, ale i na osobnosti žáka a učitele, momentálním rozpoložení žáka apod. Při zkoumání chybného výkonu jako psychického procesu Kulič zdůrazňuje složitost vzájemného působení tří aspektů, jejichž integrací každý psychický proces je - vedle obsahové, kognitivní, stránky je to jeho dynamika, tedy způsoby realizace činnosti a reakce na ni, motivace, vůle a emoce s ní spojené, a konečně typ osobnosti, který ovlivňuje přístup k chybám, a to jak ze strany žáka, tak učitele (Kulič, 1971, s. 137-165). Na některé z těchto aspektů se nyní blíže zaměříme.

\subsection{Strach z chyb}

Problematiku chyb pojímá komplexně Hejný, jenž zdůrazňuje zejména jejich diagnostickou roli, tedy nutnost chyby nejen identifikovat, ale pátrat spolu s žákem po prríčinách chyb a vhodných způsobech jejich odstranění (srov. Hejný, 2001, s. 74). Dle jeho názoru je „především nutno chybu demystifikovat, [nebot' je to právě chyba, která je často] jediná cesta ke skutečnému poznání“ (Hejný, 2001, s. 77). Zajímavým postřehem je první krok, který pro tuto demystifikaci chyby navrhuje, a to přiznání vlastní chyby ze strany učitelů, jejich popis vlastní zkušenosti s chybami, jichž se dopustili, a následná analýza. Tento krok má přispět ke značnému zmírnění, ne-li úplnému odstranění, obav z chybování u žáků a přivede učitele nejen k sebereflexi, ale mění $\mathrm{i}$ jejich přístup $\mathrm{k}$ vnímání chyb žáků a reakce na ně. Tento názor je $\mathrm{v}$ české pedagogice poměrně ojedinělý, jiní autoři se k chybám učitelů staví zcela odmítavě (viz kapitola 1.3 tohoto textu). Přestože Hejný vychází ze situace ve výuce matematiky, jeho závěry a návrhy mají obecnou platnost.

Na nutnost citlivého opravování upozorňuje i Ondráková, která poukazuje na tu skutečnost, že chyby opravované veřejně „mohou snížit sociální prestiž žáka a vést až k deformaci jeho osobnosti“ (2014, s. 39). Podobně Koštálová a Straková zdůrazňují, že hodnocení má přispět k budování pozitivního vztahu mezi učitelem a žákem a napomáhat ve společném úsilí vedoucím k dosažení cílů učení: „Učitel se nikdy nemá snažit žáka nachytat a nemá se soustředit jen na chyby, kterých se žák dopustil. V ideálním případě učitel slovo chyba vypustí ze svého slovníku." (2008, s. 10).

Nutnost přistupovat k opravám chyb nanejvýš obezřetně nás přivádí k otázce, kdo se má opravování ujmout a jakým způsobem k němu přistoupit. 


\subsection{Korektivní zpětná vazba}

„Většina lidí se shodne na tom, že chybování je součástí učení. Většina lidí se také shodne na tom, že opravování chyb je součástí vyučování." (Edge, 1989, s. 1). Ne tak jednoznačně se však jeví odpovědi na otázky, jak přesně má opravování a práce s chybami probíhat, aby byla chyba pro proces učení př́nosem, a nikoliv jeho brzdou. Jak již bylo zmíněno výše (kapitola 2.4), oprava chyb ve výuce jazyků je v současné době pojímána zejména jako poskytování korektivní zpětné vazby.

Zpětná vazba je pro žáka pomůckou na jeho cestě poznáním. Poskytuje žákovi informace o tom, jak úspěšné bylo jeho dosavadní snažení na cestě k cíli, potvrzuje úspěšné kroky a koriguje úkroky a zacházky. Čím cílenější a konkrétnější je zpětná vazba, čím je častější a časnější, tím větší je šance, že žák dosáhne vytčených cílů poznání. (Koštálová \& Straková, 2008, s. 9)

V posledních letech se otázky korektivní zpětné vazby těší značnému zájmu ze strany odborníků. Empirický výzkum poskytuje dostatek informací o tom, že KZV působí na osvojování jazyka příznivě (srov. např. Sheen \& Ellis, 2011, s. 601-607). Všechny teorie osvojování se vlivem KZV zabývají, některé jej však považují za omezený. Velký význam naopak zpětné vazbě přičítají kognitivní teorie osvojování, pro něž je př́značné zaměření na formu (focus on form), a teorie sociokulturní (Sheen \& Ellis, 2011, s. 595-597). Koncept zaměření na formu (Long, 1991) zdůrazňuje význam kontextu komunikace, jejímž hlavním cílem je sdělení významu a teprve pak zaměření na strukturu jazyka vhodného pro danou situaci. Toto pojetí je v protikladu ke staršímu zaměření na formy (focus on forms), ve kterém šlo výhradně o osvojení lingvistických forem bez ohledu na význam, typicky procvičovaných v mechanických cvičeních typu drilu (srov. např. Ellis et al., 2008, s. 255). Podrobněji bude o charakteristikách KZV pojednáno dále.

\section{Typologie korektivní zpětné vazby}

Z hlediska načasování hovoříme o okamžitě poskytované zpětné vazbě (online corrective feedback), která následuje bezprostředně po vzniku chyby, a odložené zpětné vazbě (offline corrective feedback), která je poskytnuta až poté, co skončila komunikace. U zpětné vazby na ústní projev je preferována okamžitá forma, online, ale je možná i odložená zpětná vazba, zatímco u psaní je možná jen forma offline. Při poskytování zpětné vazby v ústním projevu lze využít celé řady strategií: učitel může žákovi sám sdělit správnou formu 
(input-providing oral feedback), nebo naopak poté, co k chybě došlo, učitel signalizuje její výskyt a vyžaduje od žáka, případně dalších žáků, nápravu (output-prompting). Z hlediska formy rozlišujeme korektivní zpětnou vazbu explicitní, při níž učitel přímo opraví žákovu chybu a často poskytne také metalingvistickou informaci, například vysvětlující gramatické pravidlo, a implicitní, při níž učitel verbálně, metalingvistickou informací, nebo nonverbálně signalizuje, že došlo k chybě, a požaduje od žáka nápravu (Sheen \& Ellis, 2011, s. 593-594).

\section{Opravovat či neopravovat?}

Odborníci nejsou v otázce, zda chyby žáků opravovat nebo se opravování vyhnout, zcela jednotní. V souhrnné studii o KZV z roku 2011 uvádějí Sheen a Ellis jak rozhodné zastánce poskytování KZV, kteří zdůrazňují, že „napomáhá žákům při testování hypotéz o jazyce“ a rovněž že si „žáci přejí být opravováni“ (Hendrickson, 1978, cit. podle Sheen \& Ellis, 2011, s. 598), tak opatrnější přístup některých teoretiků. Například Urová varuje před možnými negativními důsledky nesprávně a necitlivě poskytované KZV a doporučuje spíše prevenci chyb než jejich opravování (Ur, 1996, s. 255). Podobně proti sobě v otázce opravování chyb v písemném projevu názorově stojí Truscott (1996) se svým tvrzením, že KZV nepřispívá k osvojování, a Ferrisová (1997), která se domnívá, že kvalitně poskytnutá, jasná a konzistentní KZV působí na osvojování kladně (Sheen \& Ellis, 2011, s. 598). Tento názor sdílí rovněž autoři příruček pro psaní, současně však varují před prŕlišným soustředěním se na chyby v jazyce a opomíjení chyb obsahových, stylistických a chyb ve způsobu organizace textu (Sheen \& Ellis, 2011, s. 598). Tím se dostáváme k otázce, jaké chyby mají být zvoleny k opravě, aby byla zpětná vazba účinná, přínosná a přispěla k osvojování.

\section{Co opravovat?}

Při rozhodování hraje úlohu, co za chybu považujeme, tedy otázky klasifikace chyb, jak o nich bylo pojednáno v části 1.3. Klíčovým aspektem ovlivňujícím přístup k opravování je, zda jde o chybu formy nebo významu, dále zvažujeme závažnost, zda chyba brání porozumění, nebo nikoliv, a také, je-li nutné opravit všechny chyby, k nimž došlo, nebo jen některé. V současné době převládá názor, že klíčové je, zda jde o aktivitu zaměřenou na přesnost nebo na plynulost. Při zaměření na přesnost by měly být opraveny všechny chyby, při cvičení zaměřeném na plynulost by však opravování chyb vedlo k přerušení 
žákovy samostatné promluvy a bránilo tak hlavnímu cíli, tedy sdělení významu, komunikaci. Většina odborníků se rovněž shoduje na tom, že je efektivnější opravovat selektivně - spíše chyby globální než lokální a také chyby, kterých se dopouští více studentů, nikoliv jen jednotlivci (srov. napřr. Ellis, 2009, s. 6-7). Za globální chyby (global errors) považujeme chyby, které mají vliv na větu jako celek, tedy např. chyby slovosledu, chybných spojovacích výrazů apod. Lokální chyby (local errors) jsou naproti tomu chyby, které se týkají jednotlivých slov v rámci sdělení, tedy např. chyby v morfologii a chyby gramatické (Ellis, 2009, s. 6). Tento poměrně jasný postoj však v praxi naráží na problém, kterým jsou často nejasné a obtížně definovatelné hranice mezi errors a mistakes a chybami globálními a lokálními. Jedním z možných řešení(,) podpořených závěry empirického výzkumu(,) je takzvaná cílená korektivní zpětná vazba (focused corrective feedback), zaměřená na určitý typ chyb v jedné hodině a v další na jiný jev (Sheen \& Ellis, 2011, s. 600).

\section{Kdo má opravovat a jak?}

Jakkoliv se v převládajícím současném humanistickém přístupu k výuce zaměřeném na žáka, oproti starším metodám a přístupům zaměřeným na učitele, klade důraz na opravování samotnými žáky, opravování učitelem má stále svou nezastupitelnou roli. Jedním z argumentů hovořících pro opravování učitelem je i Corderovo rozlišení chyb (1981) na chyby kompetence (errors) a chyby performance (mistakes). Už z jejich podstaty vyplývá, že žák, který si není vědom toho, že se chyby (error) dopustil, není tedy schopen ani opravy (Ellis, 2009, s. 7). Jakkoliv má tedy opravování vlastních chyb velký význam při aktivizaci žáků, není vždy možné. Učitel má však velkou škálu možností, kterou může při opravování využít.

Opravování se liší v závislosti na typu činnosti, v níž došlo k chybě, bude jiné u opravy ústního projevu a jiné v projevu písemném, rozdíly také pramení ze zaměření činnosti spíše na přesnost či plynulost. Vždy je možné využít fázované opravy, tedy nejprve na chybu upozornit a ponechat na žákovi, je-li schopen chybu opravit sám - autokorekce, dát při opravování šanci ostatním žákům - využít vrstevnickou zpětnou vazbu (peer-correction) a teprve při selhání obou přistoupit k opravě učitelem (srov. Ellis, 2009, s. 7; Ondráková, 2014, s. 148-149; Sheen \& Ellis, 2011, s. 600-601). Výzkumy prokazují, že povzbuzování studentů k autokorekci má příznivý dopad jak na rozvoj jejich autonomie, tak na učení (Sheen \& Ellis, 2011, s. 607). U vrstevnické zpětné vazby je třeba, aby učitel citlivě odhadl její vhodnost pro danou situaci. 
Účinnost vrstevnické KZV může učitel spolu s žáky podpořit vytvořením příznivého klimatu třídy (Ur, 1996, s. 171-172). Při rozhodování je vždy nutné pečlivě zvážit všechny okolnosti tak, aby přínos a efektivita poskytované KZV, pro niž se učitel rozhodne, byly pro žáky maximální.

Existuje celá řada technik, které při opravování může učitel využít - od prosté explicitní opravy přes zopakování chybné věty učitelem, ale ve správné podobě (recast), až po škálu gest či jiných předem dohodnutých nonverbálních signálů označujících výskyt chyby a její druh. Není však předmětem této práce se těmito technikami blíže zabývat.

\section{Kdy opravovat?}

Správné načasování opravy má svůj význam především u ústního projevu, nebot'v př́padě opravy psaných prací je oprava takřka vždy odložená. Chyba je v nich nejprve identifikována, zpravidla učitelem, který v př́padě potřeby i upřesní její povahu. Žák potom dostane př́ležitost chyby opravit sám a takto opravenou práci znovu předložit k hodnocení. Přestože se takový postup může zdát relativně zdlouhavý, má bezesporu velký př́nos pro efektivitu učení a posiluje autonomii žáka.

Převládající přístup ke správnému načasování oprav v ústním projevu v současné didaktice cizích jazyků je závislý na charakteru činnosti, u níž k chybě došlo. U aktivit zaměřených na přesnost se obvykle opravuje bez odkladu, u aktivit zaměřených na plynulost je oprava odložena (viz 3. 1 tohoto textu). Toto pravidlo je však bezesporu poněkud zjednodušující a jeho aplikace závisí do značné míry na individuální situaci a zkušenosti učitele. U aktivit zaměřených na plynulost může „citlivá a nápomocná intervence pomoci“, a naopak neopravujeme vždy u cvičení na přesné gramatické formy, pokud „žák pronesl zajímavou nebo osobní informaci, v níž se náhodou vyskytla ne zcela správná forma“ (Ur, 2009, s. 247).

Někteří badatelé rovněž, navzdory převládajícímu přístupu, vidí př́ležitost pozitivně ovlivnit vývoj žákovského mezijazyka tím, že i u činností zaměřených na plynulost opravují okamžitě. Svůj přístup zdůvodňují tak, že pokud se žák soustředí na význam, a nikoliv na formu, oprava pomůže jeho implicitní znalosti, a tedy i lepšímu osvojení daného jevu (Doughty, 2001, cit. podle Ellis, 2009, s. 11). 
Závěrem lze říci, že otázka vhodného načasování oprav nebyla dosud spolehlivě zodpovězena a výsledky provedených studií jsou často protichůdné (Ellis, 2009, s. 11). To však nic nemění na skutečnosti, že v každodenní praxi řeší otázky spojené s opravováním většina učitelů a svými chybami se zabývá většina žáků, nebot' jsou nedílnou součástí procesu učení.

\subsection{Opravování z pohledu učitele}

Úlohou chyby ve výuce se v českém kontextu mezi jinými zabývá prof. Hejný. Přestože jeho doménou je výuka matematiky, mnohé z jeho poznatků jsou zobecnitelné i pro výuku jiných předmětů. Podle jeho názoru jsou chyby v českém prostředí stále vnímány jako „jev nežádoucí, špatný, kterého je třeba se vystř́ihat" (Hejný \& Kuřina, 2001, s. 149). Inspiraci pro jiný přístup hledá v anglické tradici, která „chápe ve větší míře chybu jako cestu k získání zkušeností, jako součást zdravého vyučování" (Hejný \& Kuřina, 2001, s. 149).

Otázkami poskytování zpětné vazby učiteli napříč předměty, místem zpětné vazby v hodnocení a zejména změnou charakteru hodnocení a posunem od sumativního $\mathrm{k}$ formativnímu hodnocení v konstruktivistickém pojetí se zabývají v návaznosti na Neubauera (2001) a další také Koštálová a Straková (2008). Konkrétní postupy pro poskytování účinné zpětné vazby shrnují takto: „Zpětná vazba má být cílená, popisná a konkrétní. Čím je úloha pro žáky novější, tím podrobnější a popisnější musí být zpětná vazba." (s. 54). Hodnocení, jehož součástí zpětná vazba je, podporuje učení, probíhá souběžně s ním, je „procesem partnerské spolupráce učitele a žáka [...] a rodičũu, má být pro žáka motivační, povzbuzující a ukazovat mu cestu k dalšímu poznání, učit ho sebehodnocení (s. 30).

Podobně i v didaktice cizích jazyků je důležitá změna př́stupu k chybám namísto jejich výhradně negativního vnímání je potřeba na ně nahlížet jako na nezbytné kroky, které znamenají pokrok v učení a přinášejí učiteli informace o míře osvojení jazyka a žákům zpětnou vazbu, která napomůže jejich učení. „Opravování je způsob, jak studentům připomenout správné formy [...], nemělo by být kritikou ani trestem.“ (Edge,1989, s. 20). „Opravování chyb je jednou z hlavních zodpovědností učitele jazyků, které se nemůže vzdát pod záminkou přirozeněji probíhajícího vyučování, nebot' to by mělo nevyhnutelně škodlivý dopad na proces učení.“ (Pawlak, 2014, s. 85). „Korektivní zpětná vazba, at' už probíhá v mluvené, nebo psané podobě, podporuje rozvoj cizího jazyka a existují dobré důvody k jejímu využití jak při řízených aktivitách, tak při úkolech zaměřených na komunikaci.“ (Pawlak, 2014, s. 87). 


\subsection{Opravování z pohledu žáka}

Z publikovaných výzkumů o vnímání role korektivní zpětné vazby učiteli a žáky vyplývá, že obě dvě skupiny ji vnímají pozitivně. „Dostupné empirické důkazy ukazují, že jak žáci, tak učitelé se domnívají, že opravování chyb je nezbytnou součástí formálního vzdělávání, a jsou přesvědčeni o jeho př́nosu, přičemž vztah žáků $\mathrm{k}$ dané problematice je $\mathrm{v}$ tomto ohledu často podstatně kladnější než vztah učitelů." (Pawlak, 2014, s. 80). Žáci se často dožadují důkladnější analýzy svých chyb, nebot’ věří, že má nezastupitelný význam pro učení. Často také dávají přednost okamžitému a explicitnímu opravování, pokud jsou splněny určité základní podmínky. K nim patří zejména jasné stanovení cílů výuky, citlivý nezesměšňující přístup k opravování a volba vhodných strategií opravování respektující individualitu žáků.

\subsection{Vybrané poznatky empirického výzkumu o účinnosti zpětné vazby}

Korektivní zpětná vazba se v posledních letech stala častým předmětem empirického zkoumání. Studie se zaměřovaly zejména na různé techniky a strategie poskytování zpětné vazby, frekvenci jejich používání, hodnocení její účinnosti, pohled učitelů a žáků a její vliv na osvojování. Různé výzkumy však často přinesly protichůdné závěry, patrně vlivem rozdílného kontextu, v němž se uskutečnily. Rovněž interpretace výsledků není snadná, zejména proto, že na zjišt'ované skutečnosti má vliv celá řada dalších proměnných, např. individuální rozdíly mezi žáky a působení širšího kontextu (srov. Sheen \& Ellis, 2011, s. 601-604).

\section{Zpětná vazba na ústní projev}

Raný, převážně deskriptivní výzkum, (např. Allwright, 1975; Chaudron, 1977; Lyster a Ranta, 1997; Seedhouse, 1997, cit. podle Sheen \& Ellis, 2011, s. 601) vedl k vytvoření typologie strategií KZV a vyplynulo z něj, že nejčastější a nejoblíbenější formou zpětné vazby je nepřímé opravování učitelem (recast). Jiné studie však poukázaly na významné rozdíly v postojích učitelů i žáků v závislosti na širším kontextu, jak geografickém, například podstatně vyšší frekvenci používání explicitní zpětné vazby na Novém Zélandu ve srovnání s Kanadou (Lyster \& Mori, 2006, cit. podle Sheen \& Ellis, 2011, s. 602), tak na zaměření aktivity na přesnost či plynulost, formu nebo význam. $Z$ analýzy konkrétních výukových situací dále vyplynulo, že „učitelé jsou často nedůslední a nepřesní ve způsobu opravování chyb žáků" a zpětná vazba, kterou poskytují žákům tak často zůstává bez odezvy (Long, 1977, cit. podle Sheen 
\& Ellis, 2011, s. 602). Rozdíly v účinnosti KZV jsou také ovlivněny pokročilostí studentů, zatímco u vysoce pokročilých má pozitivní efekt jak učitelem poskytnutá oprava (input-providing corrective feedback), tak oprava studentem poté, co učitel upozorní na chybu (output-prompting), u nižších pokročilostí je účinnější spíše druhá forma (Ammar \& Spada, 2006, cit. podle Sheen \& Ellis, 2011, s. 603).

Lze tedy vyvodit, že výzkumná šetření z posledních let potvrdila, že korektivní zpětná vazba má, bez ohledu na použitou formu, pozitivní vliv na osvojování, je však třeba mít na paměti celou řadu faktorů, které její účinnost ovlivňují. Jasné vymezení a definice „nejlepší strategie korektivní zpětné vazby však zřejmě je chimérou“ (Ellis, 2010, cit. podle Sheen \& Ellis, 2011, s. 604).

\section{Zpětná vazba na písemný projev}

Písemná zpětná vazba se v 80 . a 90 . letech 20 . století dostala pod palbu kritiků jako přehnaně direktivní, nerespektující individualitu žáků, zbytečná, necitlivá a nedbalá (Sheen \& Ellis, 2011, s. 604). Patrně v reakci na tuto kritiku byly v 90 . letech realizovány nové studie zkoumající KZV, které opakovaně potvrdily, že „studenti velmi kladně hodnotí učitelem poskytovanou zpětnou vazbu a věří, že pomáhá zlepšit jejich psaní“ (Sheen \& Ellis, 2011, s. 604).

Významnou debatu o efektivnosti zpětné vazby ve výuce psaní zahájil svými poněkud kontroverzními závěry Truscott (1996), který tvrdí, že „by se v hodinách výuky psaní v L2 mělo upustit od opravování gramatiky“, nebot', jak ukazují výsledky výzkumu, nebyl prokázán žádný pozitivní účinek opravování a „z teoretických i praktických důvodů lze očekávat, že bude neúčinné a jeho účinek je škodlivý" (Truscott, 1996, s. 327). V reakci na tyto závěry vznikly studie, které naopak pozitivní působení písemné zpětné vazby potvrdily, zejména výzkum Ferrisové z roku 1997, který prokázal až 73\% úspěšnost studentů při opravě gramatických chyb na základě učitelem poskytnuté zpětné vazby (Ferris, 1997). Mezi dalšími zjištěními byl i fakt, že studenti ocenili zejména konkrétní opravy a návrhy, za méně přínosné považovali stručné obecné komentáře, především ty, které se vztahovaly k obsahu, a ne k formě (Sheen \& Ellis, 2011, s. 604). Protichůdné závěry Ferrisové a Truscotta probudily zájem dalších badatelů, jejich studie však vesměs nepřinesly přesvědčivé výsledky, a to zejména proto, že do výzkumu nebyla zahrnuta kontrolní skupina a předmětem zájmu byla nezacílená zpětná vazba, opravovány byly všechny typy chyb a vliv zpětné vazby nebyl posuzován v nově vytvořených úkolech. 
Ve dvou studiích provedených v prvním desetiletí 21. století (Ellis et al., 2008; Sheen, Wright, \& Moldava, 2009, cit. podle Sheen \& Ellis, 2011, s. 606) došlo $\mathrm{k}$ vylepšení metodologie výzkumu, což vedlo $\mathrm{k}$ větší průkaznosti závěrů. Výzkum se zaměřil na cílenou zpětnou vazbu, byla zahrnuta kontrolní skupina a použity pre-testy a post-testy. „Tyto studie prokázaly, že cílená zpětná vazba skutečně vede ke zlepšení jazykové přesnosti a také že čím je zpětná vazba explicitnější, tím je její přínos pro studenty větší (Sheen \& Ellis, 2011, s. 606). K omezením těchto studií však patř́ ta skutečnost, že se obě zaměřily na stejný gramatický jev, a to použití členů. Tato limitace však otvírá prostor pro další výzkum $v$ této oblasti.

\section{Doporučení pro pedagogickou praxi na základě výzkumu}

Z výsledků nedávných výzkumných šetření a analýz zaměřených na různé aspekty poskytování zpětné vazby vyplývají obecné závěry, které jsou dobře využitelné v pedagogické praxi. Jejich shrnutí přináší Sheen a Ellis (2011, s. 606-607):

1) Žáci si takřka bez výhrad přejí být opravováni.

2) Korektivní zpětná vazba, jak ústní, tak písemná, účinně napomáhá žákům ve zlepšení přesnosti jejich jazykového projevu a podporuje tak osvojování.

3) Pozitivní účinek KZV je patrný nejen u plánovaného používání jazyka, prokazujícího explicitní znalosti, ale také u neplánovaného použití jazyka, zaměřeného na význam, které prokazuje znalosti implicitní.

4) Nebylo zcela prokázáno, že by KZV musela být poskytována okamžitě, aby byl zajištěn její dopad na rozvoj mezijazyka. Jasným důkazem toho je, že KZV na písemný projev, která je vždy odložená, je účinná. Jak online/okamžitá, tak offline/odložená zpětná vazba může přispět k rozvoji jazyka.

5) Obecně vzato, největší dopad na rozvoj L2 v kontextu výuky ve třídě má taková korektivní zpětná vazba, která je explicitní a vyžaduje, aby se žák sám aktivně opravil (output prompting corrective feedback), spíše než zpětná vazba implicitní a vysvětlení poskytnuté učitelem (input-providing). Například explicitní zpětná vazba ve spojení s metalingvistickou nápovědou od učitele přispěje k učení více než zopakování s opravou (recast). 
6) Má-li KZV přispět k osvojení, musí si žáci být vědomi toho, že jsou opravováni. Skrytá zpětná vazba nemusí být vnímána jako korektivní, a je proto neúčinná.

7) Jednou z funkcí KZV je napomoci žákovi k tomu, aby se dokázal sám opravit. Principy, na nichž funguje autokorekce v ústním a písemném jazykovém projevu, je ještě třeba ozřejmit, existují však důkazy o tom, že pokud se žáci sami opravují, je pravděpodobnější, že dochází k učení.

8) Má-li být schopnost autokorekce jedním z cílů KZV, lze ho zřejmě nejlépe dosáhnout tím, že se KZV přizpůsobí dosažené úrovni L2 u jednotlivých žáků a jejich schopnosti z KZV těžit. Učitelé tomu mohou napomoci systematickým používáním implicitních forem KZV, které umožní žákovi, aby se dokázal sám opravit. ${ }^{4}$

Výzkum v oblasti zpětné vazby tedy přináší celou řadu významných podnětů pro každodenní výuku, a to nejen cizojazyčnou. Je zřejmé, že ještě mnoho aspektů této problematiky, např́klad volba vhodných strategií a technik poskytování korektivní zpětné vazby, čeká na své prozkoumání. Tato oblast se jeví jako perspektivní z hlediska výzkumu založeného v ideálním případě na těsné spolupráci mezi odborníky a učiteli.

\section{Závěr}

Otázky opravování chyb, jejich role v procesu učení a jejich vlivu na osvojování cizích jazyků měly své místo $\mathrm{v}$ různých didaktických přístupech a metodách cizojazyčné výuky. I přesto, že se v některých obdobích na chyby pohlíželo jako na selhání a v jiných se projevovaly snahy o to zabránit žákům v chybování docela prostřednictvím přesně řízených drilů, v dnešním eklektickém přístupu je korektivní zpětná vazba a opravování chyb nedílnou součástí procesu učení a vyučování. Účinnost korektivní zpětné vazby a její kladný vliv na osvojování byly potvrzeny řadou empirických studií. Velká pozornost byla a je věnována zejména aspektům klasifikace chyb, hledání účinných strategií opravování a poskytování zpětné vazby, potřebě individuálního přístupu k žákům, který bere $\mathrm{v}$ úvahu jejich věk, motivaci, schopnosti a předpoklady $\mathrm{k}$ učení, upřednostňování různých stylů učení a řadu jiných faktorů, stejně jako širšímu kontextu, v němž učení probíhá. Přestože v těchto oblastech panují často různé, i protichůdné, názory, o pozitivní roli opravování a jeho nezastupitelném místě v učení není pochyb.

\footnotetext{
$4 \quad$ Veškeré uvedené citáty $\mathrm{z}$ anglicky psaných zdrojů byly volně přeloženy autorkou textu.
} 


\section{Poděkování}

Autorka děkuje členům redakce, zejména panu docentu Slavíkovi, za cenné podněty a odborné připomínky, jakož i za doporučenou literaturu, a také anonymním recenzentům za inspirativní a podrobné komentáře k předkládanému textu. Poděkování patří i doc. Janíkovi za prvotní povzbuzení k napsání této studie.

\section{Literatura}

Adam, R. (2008). Nad knihou o jazykové regulaci. Naše řeč, 92(3), 145-155.

Allwright, R. (1975). Problems in the study of the language teacher's treatment of learner error. In M. Burt, \& H. Dulay (Eds.), On TESOL'75: New directions in language learning, teaching, and bilingual education (s. 96-109). Washington: TESOL.

Allwright, D., \& Bailey, K. M. (1991). Focus on the language classroom: An introduction to classroom research for language teachers. Cambridge: CUP.

Ammar, A., \& Spada, N. (2006). One size fits all?: Recasts, prompts, and L2 learning. Studies in Second Language Acquisition, 28(4), 543-574.

Balada, J., Baladová, G., Boněk, J., Brant, J., Brychnáčová, E., Doležalová, O. ... Zelendová, E. (2007). Rámcový vzdělávací program pro gymnázia. Praha: Výzkumný ústav pedagogický v Praze.

Bambgbose, A. (1998). Torn between the norms: innovations in world Englishes. World Englishes, 17(1), 1-14.

Brown, H. D. (2001). Teaching by principles: An interactive approach to language pedagogy. New York: Longman.

Brown, H. D. (2002). English language teaching in the „Post-method“ era: Towards better diagnosis, treatment, and assessment. In J. C. Richards \& W. A. Renandya (Eds.), Methodology in language teaching: An anthology of current practice (s. 9-18). Cambridge: CUP.

Brumfit, C. (1984). Communicative methodology in language teaching the roles of fluency and accuracy. Cambridge: CUP.

Carter, R., \& McCarthy, M. (1997). Exploring spoken English. Cambridge: CUP.

Corder, S. P. (1981). Error analysis and interlanguage. Oxford: OUP.

Crystal, D. (2003). English as a global language. Cambridge: CUP.

Cvrček, V. (2008). Regulace jazyka a koncept minimální intervence. Praha: Nakladatelství Lidové noviny.

Cvrček, V., \& Kováříková, D. (2011). Možnosti a meze korpusové lingvistiky. Naše řeč, 94(3), 113-133.

Deyuan, H., \& Qunying, Z. (2010). Native speaker norms and China English: From the perspective of learners and teachers in China. TESOL Quarterly, 44(4), 769-789.

Edge, J. (1989). Mistakes and correction. London: Longman.

Ellis, R. (1994a). The study of second language acquisition. Oxford: OUP.

Ellis, R. (1994b). Understanding second language acquisition. Oxford: OUP.

Ellis, R. (2009). Corrective feedback and teacher development. L2 Journal, 1(1), 3-18. 
Ellis, R. (2010). Cognitive, social, and psychological dimensions of corrective feedback. In R. Batstone (Ed.), Sociocognitive perspectives on language use and language learning (s. 151-165). Oxford: OUP.

Ellis, R., \& Barkhuizen, G. (2005). Analysing learner language. Oxford: OUP.

Ellis, R., Sheen, Y., Murakami, M., \& Takashima, H. (2008). The effects of focused and unfocused written corrective feedback in an English as a foreign langauge context. System, 36(3), 353-371.

Ferris, D. R. (1997). The influence of teacher commentary on student revision. TESOL Quarterly, 31(2), 315-339.

Finocchiaro, M., \& Brumfit C. (1983). The functional-notional approach: From theory to practice. New York: OUP.

Gower, R., Walters, S., \& Phillips, D. (1995). Teaching practice handbook. Oxford: Heinemann.

Graddol, D. (2006). English next. Plymouth: British Council.

Hanušová, S. (2003). Pregraduální př́́prava učitelů anglického jazyka na fakultách vysokých škol v ČR. Pedagogická orientace, 13(1), 17-33.

Hejný, M. (2001). Chyba jako pedagogický fenomén. In Z. Moussová \& S. Štech (Eds.), Dítě škola - učitel (s. 72-81). Praha: UK v Praze.

Hejný, M., \& Kuřina, F. (2001). Dítě, škola a matematika: konstruktivistické přístupy k vyučování. Praha: Portál.

Hendrich, J. (1988). Didaktika cizích jazyků. Praha: SPN.

Homoláč, J., \& Nebeská, I. (2000). Př́íspěvek ke kritické analýze pojmu jazyková norma. Slovo a slovesnost, 61(2), 102-109.

Homoláč, J., \& Mrázková, K. (2011). Jazyková regulace jako věc dohody. Slovo a slovesnost, 72(3), $196-222$.

Hrdlička, M. (2012). Jazyková chyba a práce s ní v jazykovém vyučování. In K. Šebesta \& S. Škodová (Eds.), Čeština - cílový jazyk a korpusy (s. 89-108). Liberec: TU Liberec.

Chaudron, C. (1977). A descriptive model of discourse in the corrective treatment of learners'errors. Language Learning, 27(1), 29-46.

Choděra, R., \& Ries, L. (1999). Výuka cizích jazyků na prahu nového století. Ostrava: Ostravská univerzita.

Choděra, R. (2013). Didaktika cizích jazyků. Praha: Academia.

Chomsky, N. (2007). On language, Chomsky's classic works language and responsibility and reflections on language. New York: New Press.

Ivanová, J., Lenochová, A., Linková, J., \& Šimáčková, Š. (2006). Společný evropský referenční rámec pro jazyky. Olomouc: Univerzita Palackého v Olomouci.

Janík, T., \& Stuchlíková, I. (2010). Oborové didaktiky na vzestupu: přehled aktuálních vývojových tendencí. Scientia in educatione, 1(1), 5-32.

Jedlička, A. (1982). Typy norem jazykové komunikace. Slovo a slovesnost, 43(4), 272-281.

Jenkins, J. (2000). The phonology of English as a lingua franca. Oxford: OUP.

Jenkins, J. (2003). World Englishes. London: Routledge.

Jenkins, J. (2007). English as a lingua franca: Attitude and identity. Oxford: OUP.

Jodai, H., Pirhadi, J., \& Taghavi, M. (2014). Attitudes towards native speaker norms: Evidence from an Iranian context. Procedia - Social and behavioral sciences, 98, 789-798. 
Kačala, J. (2009). Systémové základy jazyka a jazykovej kultury. In M. Považaj (Ed.), Jazyková kultúra na začiatku tretieho tisícročia (s. 25-31). Bratislava: Veda.

Kachru, B. (1985). Standards, codification and sociolinguistic realism: The English language in the outer circle. In R. Quirk \& H. G. Widdowson (Eds.), English in the world: Teaching and learning the language and literatures (s. 11-30). Cambridge: CUP.

Kalová, S. (2017, v tisku). Problematika jazykové normy ve výuce angličtiny. Filologické štúdie, 3.

Kirkpatrick, A. (2006). Which model of English: Native-speaker, nativised or lingua franca? In R. Rubdy \& M.Saraceni (Eds.), English in the world: Global rules, global roles (s. 71-83). London: Continuum.

Kočiš, F. (1979). Pojem jazykovej normy a normovanosti. In J. Kačala (Ed.), Z teorie spisovného jazyka. Zborník referátov a diskusných príspevkov (s. 32-42). Bratislava: Veda.

Koníčková, Š. (2015). Odborný jazyk v oblasti marketingu u studentů francouzštiny UP v Olomouci. Olomouc: UP v Olomouci.

Koštálová, H., \& Straková J. (2008). Hodnocení: důvěra, dialog, růst. Praha: SKAV.

Kumaravadivelu, B. (2006). TESOL methods: Changing tracks, challenging trends. TESOL Quarterly, 40(1), 59-81.

Kumaravadivelu, B. (2007). Understanding language teaching: From method to postmethod. Mahwah: Taylor \& Francis e-Library.

Kumorová, Z. (2015). Základy teórie spisovného jazyka a jazykovej kultury. Trnava: Univerzita sv. Cyrila a Metoda.

Kulič, V. (1971). Chyba a učení. Praha: SPN.

Lado, R. (1957). Linguistics across cultures. Ann Arbor: Univesity of Michigan Press.

Larsen-Freeman, D. (2000). Techniques and principles in language teaching. Oxford: OUP.

Larsen-Freeman, D., \& Anderson M. (2011). Techniques and principles in language teaching. Oxford: OUP.

Ligtbown, P., \& Spada, N. (2013). How languages are learned. Oxford: OUP.

Long, M. (1977). Teacher feedback on learner error: Mapping cognitions. In H. D. Brown, C. A. Yorio, \& R. H. Crymes (Eds.), On TESOL '77 (s. 278-293). Washington: TESOL.

Long, M. (1991). Focus on form: A design feature in language teaching methodology. In K. de Bot, R. Ginsberg, \& C. Kramsch (Eds.), Foreign language research in cross-cultural perspective (s. 39-52). Amsterdam: John Benjamins.

Lyster, R., \& Mori, H. (2006). Interactional feedback and instructional counterbalance. Studies in Second Language Acquisition, 28(2), 269-300.

Lyster, R., \& Ranta, L. (1997). Corrective feedback and learner uptake: Negotiation of form in communicative classrooms. Studies in Second Language Acquisition, 19(1), 37-66.

Mareš, J. (2013). Pedagogická psychologie. Praha: Portál.

Mothejzíková, J. (1995). Výuka cizím jazykům na sklonku tisíciletí. Cizí jazyky, 38(5-6), 170-183.

MŠMT. (1996). Učební osnovy základní školy předmětu cizí jazyk pro třídy s rozšířeným vyučováním jazyků. Dostupné z http://www.msmt.cz/file/38746

Neubauer, Z. (2001). Smysl a svět. Praha: Nadace Dagmar a Václava Havlových Vize 97.

Nebeská, I. (1992). Dvojí poloha pojmu jazyková norma. Naše řeč, 75(1), 22-27.

Nebeská, I. (1999). Jazyk, norma, spisovnost. Praha: Nakladatelství Karolinum.

Ondráková, J. (2014). Chyba a výuka cizích jazyků. Hradec Králové: Gaudeamus. 
Önen, S. (2015). The use of prepositions in English as lingua Franca interactions: Corpus ISTErasmus. Journal of Education and Practice, 6(5), 160-172.

Pawlak, M. (2014). Error correction in the foreign language classroom. Reconsidering the issues. Heidelberg: Springer-Verlag.

Prabhu, N. S. (1990). There is no best method - why? TESOL Quarterly, 24(2), 161-176.

Průcha J., Walterová E., \& Mareš J. (2009). Pedagogický slovník. Praha: Portál.

Quine, M. V. O. (2008). Covitosti (Občasně filosofický slovník). Praha: Mladá fronta.

Richards, J. C., \& Rodgers T. S. (2001). Approaches and methods in language teaching. Cambridge: CUP.

Saville-Troike, M. (2006). Introducing second language acquisition. Cambridge: CUP.

Seedhouse, P. (1997). The case of the missing „no": The relationship between pedagogy and interaction. Language Learning, 47, 547-583.

Seidlhofer, B. (2004). Research perspectives on teaching English as a lingua franca. Annual Review of Applied Linguistcs, 24, 209-239.

Seidlhofer, B. (2011). Understanding English as a lingua franca. Oxford: OUP.

Selinker, L. (1972). Interlanguage. IRAL: International Review of Applied Linguistics in Language Teaching, 10(3), 209.

Sheen, Y., \& Ellis, R. (2011). Corrective feedback in language teaching In E. Hinkel (Ed.), Handbook of research in second language teaching and learning (s. 593-610). New York: Routledge.

Sheen, Y., Wright, D., \& Moldava, A. (2009). Differential effects of focused and unfocused written correction on the accurate use of grammatical forms by adult ESL learners. System, 37(4), 556-559.

Slavík, J. (1994). Problém chyby v tvořivé výrazové výchově. Pedagogika, 44(2), 119-128.

Slavík, J. (1999). Hodnocení v současné škole. Praha: Portál.

Smolder, C. (2009). ELT and the native speaker ideal: Some food for thought. International House Journal of Education and Development, 26(22).

Šed'ová K., \& Švaříček, R. (2010). Zamlčené hodnocení: zpětná vazba ve výukové komunikaci na druhém stupni základní školy. Studia paedagogica, 15(2), 61-68.

Šed'ová, K., \& Švaříček, R. (2012). Feedback in educational communication in Czech secondary schools. Educational Assessment, Evaluation and Accountability, 24(3) 239-261.

Švrčinová, M. (2014). Práce s chybou ve výuce cizích jazyků (včetně češtiny pro cizince). Praha: UK v Praze.

Timmis, I. (2002). Native-speaker norms and international English: A classroom view. ELT Journal Volume, 56(3), 240-249.

Truscott, J. (1996). The case against grammar correction in L2 writing classes. Language Learning, 46(2), 327-369.

Tůmová, J. (2004). Společný evropský referenční rámec pro jazyky a cizí jazyk v RVP ZV. Dostupné zhttps://clanky.rvp.cz/clanek/c/z/45/SPOLECNY-EVROPSKY-REFERENCNI-RAMEC-PROJAZYKY-A-CIZI-JAZYK-V-RVP-ZV.html/

Ur, P. (2009). A course in language teaching. Cambridge: CUP.

Walker, R. (2010). Teaching the pronunciation of English as a lingua franca. Oxford: OUP. 


\title{
Autorka
}

PhDr. Simona Kalová, Masarykova univerzita, Filozofická fakulta, Gorkého 7, 60200 Brno, e-mail: kalova@phil.muni.cz

\section{The role of errors, corective feedback, and norm in foreign language teaching, with focus on teaching English}

\begin{abstract}
This study seeks to explore the area of error correction and the role it has in foreign language teaching, with the main focus on teaching English. It aims to compare Czech and international studies in error correction and corrective feedback, and draw general principles applicable in teaching. A detailed account of the question of language norm with focus on the specific situation of the English language and its impact on teaching English as a second and foreign language is provided. This area, with often conflicting views from experts, is one of the thriving research areas in ELT, not sufficiently described in the Czech context. In the first chapter, theoretical key concepts - error and norm - are defined, followed by the second chapter which takes a diachronic view of attitudes to error correction. In the final part, the findings of current research into approaches to error correction and corrective feedback are provided. These should be taken into account so that they were a help rather than a hindrance to teaching. The results support the idea that the choice of effective strategies of corrective feedback depending on the concrete teaching context is of vital importance.
\end{abstract}

Keywords: foreign language teaching, English language teaching, error, language norm, corrective feedback

Slavík, J., Uličná, K., Stará, J., Najvar, P. et al. (2017). Didaktické kazuistiky v oborech školního vzdělávání. Brno: Munipress.

Kniha představuje didaktickou kazuistiku jako nástroj pro kultivaci (oborově) didaktického myšlení. $V$ první části je představen pojem kazuistika v souvislosti s výzkumem v klinických vědách. Zvláštní pozornost je potom věnována didaktickým kazuistikám a jejich roli v transdisciplinárním didaktickém výzkumu a představení transdidaktického př́stupu využívajícího metodiku 3A. Druhou část knihy tvoří vybrané didaktické kazuistiky zpracované týmem oborových didaktiků a učitelů v praxi. 